\title{
Rhizobial Diversity and Nodulation Characteristics of the Extremely Promiscuous Legume Sophora flavescens
}

\author{
Yin Shan Jiao, ${ }^{1}$ Yuan Hui Liu, ${ }^{1}$ Hui Yan, ${ }^{1}$ En Tao Wang, ${ }^{1,2}$ Chang Fu Tian, ${ }^{1}$ Wen Xin Chen, ${ }^{1}$ Bao Lin Guo, ${ }^{3}$ \\ and Wen Feng Chen ${ }^{1}$ \\ ${ }^{1}$ State Key Laboratory of Agrobiotechnology, Beijing 100193, China; College of Biological Sciences and Rhizobia Research \\ Center, China Agricultural University, Beijing 100193, China; ${ }^{2}$ Departamento de Microbiología, Escuela Nacional de Ciencias \\ Biológicas, Instituto Politécnico Nacional, México D. F. 11340, México; ${ }^{3}$ Institute of Medicinal Plant Development, Chinese \\ Academy of Medical Sciences and Peking Union Medical College, Beijing 100193, China
}

Submitted 15 June 2015. Accepted 13 September 2015.

In present study, we report our extensive survey on the diversity and biogeography of rhizobia associated with Sophora flavescens, a sophocarpidine (matrine)-containing medicinal legume. We additionally investigated the cross nodulation, infection pattern, light and electron microscopies of root nodule sections of $S$. flavescens infected by various rhizobia. Seventeen genospecies of rhizobia belonging to five genera with seven types of symbiotic nodC genes were found to nodulate $S$. flavescens in natural soils. In the cross-nodulation tests, most representative rhizobia in class $\alpha$-Proteobacteria, whose host plants belong to different cross-nodulation groups, form effective indeterminate nodules, while representative rhizobia in class $\beta$-Proteobacteria form ineffective nodules on $S$. flavescens. Highly host-specific biovars of Rhizobium leguminosarum (bv. trifolii and bv. viciae) and Rhizobium etli bv. phaseoli could establish symbioses with S. flavescens, providing further evidence that $S$. flavescens is an extremely promiscuous legume and it does not have strict selectivity on either the symbiotic genes or the species-determining housekeeping genes of rhizobia. Root-hair infection is found as the pattern that rhizobia have gained entry into the curled root hairs. Electron microscopies of ultra-thin sections of $S$. flavescens root nodules formed by different rhizobia show that the bacteroids are regular or irregular rod shape and nonswollen types. Some bacteroids contain poly- $\beta$-hydroxybutyrate (PHB), while others do not, indicating the synthesis of PHB in bacteroids is rhizobia-dependent. The extremely promiscuous symbiosis between $S$. flavescens and different rhizobia provide us a basis for future studies aimed at understanding the molecular interactions of rhizobia and legumes.

The association between leguminous plants and symbiotic nitrogen-fixing rhizobia is one of the most important symbioses and has attracted extensive studies. In rhizobia, the nodulation (nod) genes encoding for Nod factors are believed to be the determinants of rhizobial host specificity (Dénarié et al. 1996; Ferguson 2013). Based upon the differences in their nod genes, some rhizobial strains can only nodulate limited plant species, such as Mesorhizobium muleiense CCBAU $83963^{\mathrm{T}}$ for Cicer

Corresponding author: Wen Feng Chen; Telephone: +86 106273 4009; E-mail: chenwf@cau.edu.cn

*The $\boldsymbol{e}$-Xtra logo stands for "electronic extra" and indicates that seven supplementary figures and one supplementary table are published online.

(c) 2015 The American Phytopathological Society arietinum (Zhang et al. 2012), while other strains, such as Sinorhizobium sp. strain NGR234, have a broad host range and can nodulate with many different legumes, even the nonlegume Parasponia andersonii (Pueppke and Broughton 1999). Similarly, some legumes, like Astragalus sinicus (Wang et al. 2014), Medicago truncatula (Barker et al. 1990), and Cicer arietinum (Zhang et al. 2012) are hosts specific for a limited number of rhizobial species or even strains. In contrast, other legumes, such as common bean (Phaseolus vulgaris) (Michiels et al. 1998), Acacia tortilis (Ba et al. 2002), Siratro (Macroptilium atropurpureum) (Angus et al. 2013; Moulin et al. 2001), Sophora alopecuroides (Zhao et al. 2010), Sarothamnus scoparius (Sajnaga et al. 2001), and the nonlegume Parasponia andersonii (Op den Camp et al. 2012) are known as promiscuous hosts.

The legume genus Sophora contains about 50 species, in which the nodulation of about 20 species is documented (Sprent 2001), and fewer of them have been studied about their rhizobia in detail (Sprent 2001; Zhao et al. 2010). Previously, various rhizobia belonging to 11 genospecies in six genera harboring five nodA gene types have been isolated from the root nodules of Sophora alopecuroides (Han et al. 2008; Zhao et al. 2010). Most recently, Tan et al. (2015) studied 48 rhizobial isolates from the New Zealand native Sophora spp. and found that all isolates were classified into genus Mesorhizobium. These results demonstrate that Sophora spp. are a promiscuous host for diverse rhizobia.

Sophora flavescens, another species in genus Sophora, is a perennial medicinal plant native to northeastern Asia (Han et al. 2015). It is increasingly cultured in north China, since the nitrogen-containing sophocarpidine (matrine) in its roots acts as a traditional insecticide and an anticarcinogen (Han et al. 2015). Crow et al. (1981) reported that $S$. flavescens was a distinctive species and that the rhizobia isolated from $S$. angustifolia could nodulate $S$. flavescens, while others suggested that these two species were synonymous (Sprent 2001; 2009). Despite the nomenclature argument, the rhizobia associated with S. flavescens and their nodulation procedures have not yet been studied extensively. Three novel species, Rhizobium sophorae, Rhizobium sophoriradicis, and Phyllobacterium sophorae, were just recently recorded by our research group (Jiao et al. $2015 \mathrm{a}$ and b). Because of the wider distribution of $S$. flavescens than $S$. alopecuroides, it is possible that the genetic diversity of rhizobia is greater in the former than the latter.

In this study, we performed the first systematic analysis of the genetic diversity and distribution of rhizobia isolated from root nodules of $S$. flavescens grown in different ecoregions. Based on these results, we then carried out extensive 
cross-nodulation tests under laboratory conditions to explore the symbiotic promiscuity of $S$. flavescens. In addition, morphologies of the root nodule and nodule section, the infection process, and the presence of the bacteroids in the nodule cells were examined. Our studies revealed that $S$. flavescens is an extremely promiscuous host for various rhizobia and it can serve as a good candidate for future studies on the symbiotic relationship between rhizobia and legumes.

\section{RESULTS}

Isolation of root-nodule bacteria and soil characterization.

In total, 269 pure rhizobial isolates were obtained from Sophora flavescens nodules collected from three ecoregions (Supplementary Table S1). Except for three isolates (CCBAU 03429, CCBAU 03419, and CCBAU 71316), the remaining 266 isolates formed effective nodules on S. flavescens, as evidenced by the bright green leaves and the red color of the nodule section (Supplementary Fig. S3).

The results of soil characteristics showed that the three ecoregions differed mainly in soil $\mathrm{pH}$ values. Ecoregion I in Shanxi province had a slightly alkaline soil (7.26 to 7.95), ecoregion II in Shaanxi province had an acidic soil (5.44 to 6.68), and ecoregion III in Liaoning province had an alkaline soil (8.36 to 8.59) (Table 1). In addition, ecoregion I had a much higher concentration of available potassium (AK) than the other two ecoregions. Ecoregion III had total nitrogen content, organic matter, available nitrogen, available phosphorus, available potassium, and total salt levels lower than those of the other two ecoregions (Table 1).

\section{Genetic diversity and distribution of rhizobia associated with $S$. flavescens.}

Based on analysis of the $r e c A$ gene sequence screening, 17 genotypes were identified and 35 representative isolates were further characterized with a multilocus sequence analysis (MLSA) of three housekeeping genes ( $a t p D, g \ln I I$, and $r e c A)$. In the maximum likelihood phylogenetic tree reconstructed with the MLSA data, these 35 representative isolates were classified into 17 genospecies (Fig. 1; Table 2), belonging to genera Bradyrhizobium, Sinorhizobium, Mesorhizobium, Rhizobium, and Phyllobacterium. Nine genospecies corresponding to Sinorhizobium fredii, Mesorhizobium septentrionale, Bradyrhizobium elkanii, Rhizobium yanglingense, Mesorhizobium sp. strain I, $R$. sophorae, $R$. sophoriradicis, Mesorhizobium huakuii, and Rhizobium sp. strain I were the major groups containing 12 to 46 isolates (Table 2). Sinorhizobium fredii was the most widely spread major genospecies occurring on eight sites (S3, S4, S7 to S11, and S18). Eight genospecies, including Phyllobacterium sophorae, Bradyrhizobium sp. strain I, Mesorhizobium sp. strain II, $R$. mongolense, $R$. lusitanum, Rhizobium spp. II, III, and V were minor groups containing 1 to 4 isolates (Table 2), which were found in one to three sampling sites.

The highest diversity index of Shannon-Weiner $\left(H^{\prime}\right)$ was found on site S18 (1.68), followed by that on site S5 (1.58) and site S17 (1.22) (Table 2), and seven genospecies were found on each of these three sites. The lowest $H^{\prime}$ values $(0)$ were found on sites S2, S9, S10, S14, and S15, with only one genospecies isolated on those sites. The other sampling sites had $H^{\prime}$ values ranging from 0.97 to 0.30 . The values of Simpson's index $(D)$ varied between 0.78 and 0 on 18 sampling sites and were well consistent with the $H^{\prime}$ values. Evenness index Pielou $(J)$ varied from 0.97 , in the case of sites S1 and S7, to 0.27 , in the case of site S16. These results demonstrated that the diversity and genospecies composition of the rhizobial community associated with S. flavescens varies on different sampling sites.

\section{Soil factors influencing the geographic distribution of rhizobia.}

According to the length of the arrows (the longer the arrow, the more highly related that this variable is to the genospecies distribution) and the angles between the arrow and the genospecies (the smaller, the more closely related) shown in Figure 2, the soil $\mathrm{pH}$, total salt, and available potassium had an obviously positive correlation with the distribution of genospecies isolated from ecoregion I, but a negative correlation with the distribution of genospecies isolated from ecoregion II and III. Soil $\mathrm{pH}$ is one of the most important soil factors related to the distribution of

Table 1. Geographic information, climate, and soil characteristics of the 18 sampling sites

\begin{tabular}{|c|c|c|c|c|c|c|c|c|c|c|c|}
\hline \multirow{2}{*}{$\begin{array}{l}\text { Ecoregion, a geographic } \\
\text { origin, and sampling sites }\end{array}$} & \multirow[b]{2}{*}{ Altitude (m) } & \multicolumn{2}{|c|}{ GPS } & \multirow{2}{*}{$\begin{array}{l}\text { Rainfall } \\
(\mathbf{m m})^{\mathbf{b}}\end{array}$} & \multicolumn{7}{|c|}{ Soil characteristics ${ }^{c}$} \\
\hline & & Longitude & Latitude & & $\mathbf{T N}$ & $\mathbf{O M}$ & $\mathbf{A N}$ & $\mathbf{A P}$ & AK & TS & $\mathbf{p H}$ \\
\hline \multicolumn{12}{|l|}{ Ecoregion I: Shanxi province } \\
\hline S1: Zhenxin town, Changzhi & 1,224 & $113^{\circ} 03^{\prime} 08^{\prime \prime} \mathrm{E}$ & $36^{\circ} 02^{\prime} 24^{\prime \prime} \mathrm{N}$ & 411 & 1.18 & 16.7 & 70.0 & 5.9 & 436 & 0.75 & 7.95 \\
\hline S2: Zhenxin town, Changzhi & 1,224 & $113^{\circ} 03^{\prime} 10^{\prime \prime} \mathrm{E}$ & $36^{\circ} 02^{\prime} 27^{\prime \prime} \mathrm{N}$ & 411 & 1.06 & 15.4 & 53.4 & 56.7 & 138 & 0.70 & 7.52 \\
\hline S3: Zhenxin town, Changzhi & 1,224 & $113^{\circ} 03^{\prime} 09^{\prime \prime} \mathrm{E}$ & $36^{\circ} 02^{\prime} 30^{\prime \prime} \mathrm{N}$ & 411 & 0.82 & 16.3 & 42.0 & 19.9 & 122 & 0.83 & 7.76 \\
\hline S4: Wugu Mt., Changzhi & 1,041 & $113^{\circ} 03^{\prime} 02^{\prime \prime} \mathrm{E}$ & $36^{\circ} 02^{\prime} 24^{\prime \prime} \mathrm{N}$ & 411 & 1.43 & 30.4 & 44.3 & 25.8 & 170 & 1.27 & 7.26 \\
\hline S5: Niusi town, Qinxian & 993 & $112^{\circ} 03^{\prime} 30^{\prime \prime} \mathrm{E}$ & $36^{\circ} 54^{\prime} 36^{\prime \prime} \mathrm{N}$ & 606 & 0.89 & 11.4 & 58.5 & 14.8 & 273 & 0.85 & 7.75 \\
\hline S6: Niusi town, Qinxian & 993 & $112^{\circ} 03^{\prime} 36^{\prime \prime} \mathrm{E}$ & $36^{\circ} 54^{\prime} 35^{\prime \prime} \mathrm{N}$ & 606 & 0.94 & 10.3 & 44.5 & 25.4 & 390 & 0.86 & 7.78 \\
\hline S7: Hanbei town, Wuxiang & 1,225 & $113^{\circ} 11^{\prime} 56^{\prime \prime} \mathrm{E}$ & $36^{\circ} 45^{\prime} 40^{\prime \prime} \mathrm{N}$ & 560 & 1.01 & 23.0 & 103.0 & 33.4 & 398 & 0.91 & 7.76 \\
\hline S8: Hanbei town, Wuxiang & 1,225 & $113^{\circ} 11^{\prime} 55^{\prime \prime} \mathrm{E}$ & $36^{\circ} 45^{\prime} 25^{\prime \prime} \mathrm{N}$ & 560 & 1.02 & 28.4 & 90.4 & 10.9 & 322 & 0.90 & 7.81 \\
\hline S9: Hanbei town, Wuxiang & 1,225 & $113^{\circ} 11^{\prime} 57^{\prime \prime} \mathrm{E}$ & $36^{\circ} 45^{\prime} 32^{\prime \prime} \mathrm{N}$ & 560 & 0.90 & 17.7 & 50.9 & 20.8 & 470 & 0.73 & 7.91 \\
\hline S10: Hanbei town, Wuxiang & 1,225 & $113^{\circ} 11^{\prime} 49^{\prime \prime} \mathrm{E}$ & $36^{\circ} 45^{\prime} 35^{\prime \prime} \mathrm{N}$ & 560 & 1.19 & 23.8 & 52.2 & 7.3 & 316 & 0.67 & 7.84 \\
\hline S11: Hanbei town, Wuxiang & 1,225 & $113^{\circ} 11^{\prime} 50^{\prime \prime} \mathrm{E}$ & $36^{\circ} 45^{\prime} 31^{\prime \prime} \mathrm{N}$ & 560 & 1.06 & 20.9 & 57.3 & 16.7 & 562 & 0.80 & 7.91 \\
\hline \multicolumn{12}{|l|}{ Ecoregion II: Shaanxi province } \\
\hline S12: Maping town, Luonan & 1,066 & $110^{\circ} 04^{\prime} 10^{\prime \prime} \mathrm{E}$ & $34^{\circ} 12^{\prime} 06^{\prime \prime} \mathrm{N}$ & 700 & 1.27 & 18.4 & 52.7 & 23.1 & 93 & 0.41 & 5.80 \\
\hline S13: Maping town, Luonan & 1,066 & $110^{\circ} 04^{\prime} 03^{\prime \prime} \mathrm{E}$ & $34^{\circ} 12^{\prime} 11^{\prime \prime} \mathrm{N}$ & 700 & 1.33 & 18.0 & 123.0 & 34.8 & 80 & 0.43 & 5.44 \\
\hline S14: Maping town, Luonan & 1,050 & $110^{\circ} 03^{\prime} 59^{\prime \prime} \mathrm{E}$ & $34^{\circ} 12^{\prime} 06^{\prime \prime} \mathrm{N}$ & 700 & 1.43 & 20.2 & 89.3 & 25.5 & 110 & 0.45 & 5.57 \\
\hline S15: Youfang town, Luonan & 1,109 & $110^{\circ} 02^{\prime} 44^{\prime \prime} \mathrm{E}$ & $34^{\circ} 13^{\prime} 14^{\prime \prime} \mathrm{N}$ & 700 & 1.06 & 13.0 & 83.5 & 18.9 & 65 & 0.53 & 6.68 \\
\hline \multicolumn{12}{|c|}{ Ecoregion III: Liaoning province } \\
\hline S16: Heishui, Jianping & 554 & $119^{\circ} 29^{\prime} 48^{\prime \prime} \mathrm{E}$ & $42^{\circ} 03^{\prime} 33^{\prime \prime} \mathrm{N}$ & 500 & 0.74 & 8.18 & 49.8 & 9.0 & 86 & 0.47 & 8.36 \\
\hline S17: Changlong, Jianping & 526 & $119^{\circ} 23^{\prime} 16^{\prime \prime} \mathrm{E}$ & $41^{\circ} 58^{\prime} 41^{\prime \prime} \mathrm{N}$ & 500 & 0.47 & 5.6 & 36.6 & 1.6 & 40 & 0.64 & 8.59 \\
\hline S18: Yangshuling, Jianping & 690 & $119^{\circ} 45^{\prime} 58^{\prime \prime} \mathrm{E}$ & $41^{\circ} 50^{\prime} 36^{\prime \prime} \mathrm{N}$ & 500 & 0.73 & 9.29 & 49.2 & 7.3 & 81 & 0.55 & 8.46 \\
\hline
\end{tabular}

${ }^{a}$ Ecoregion I: clay loam, semihumid, alkaline soil; ecoregion II: sandy loam, moist, acid soil; and ecoregion III: sandy loam, semiarid land, highly alkaline soil.

b Mean annual rainfall $(\mathrm{mm})$.

${ }^{\mathrm{c}} \mathrm{TN}$, total nitrogen content (g/kg); OM, organic matter (g/kg); AN, available nitrogen (mg/kg); AP, available phosphorus (mg/kg); AK, available potassium (K) $(\mathrm{mg} / \mathrm{kg})$; TS, total salt $(\mathrm{g} / \mathrm{kg})$; and $\mathrm{pH}$, soil $\mathrm{pH}$. 


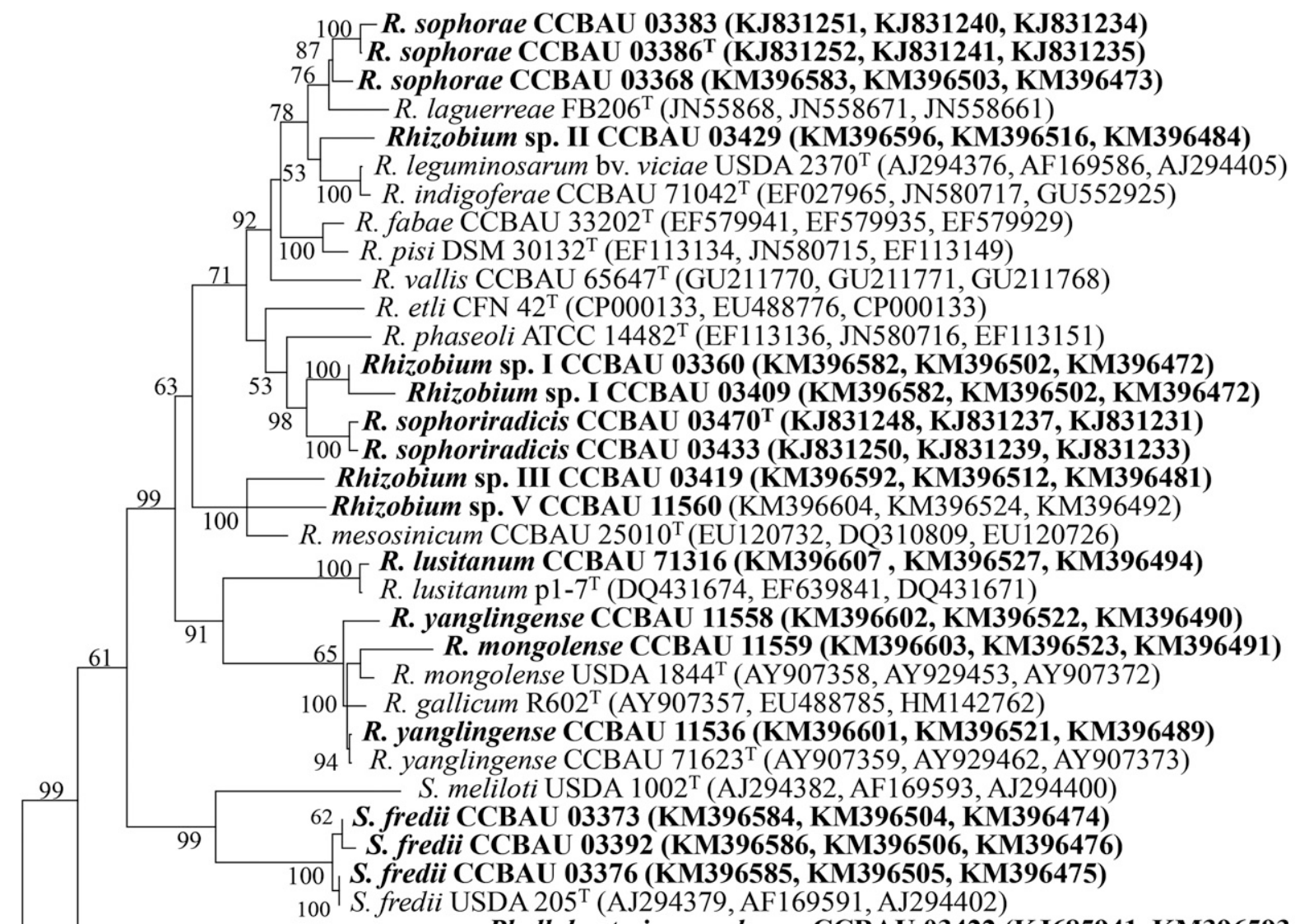

$87 R$ sophorae CCBAU 03386 T (KJ831252, KJ831241, KJ831235)

$76 \leftarrow R$. sophorae CCBAU 03368 (KM396583, KM396503, KM396473)

$R$. laguerreae $\mathrm{FB} 206^{\mathrm{T}}$ (JN55868, JN558671, J

- R. fabae CCBA

R. pisi DSM 30132T (EF113134, JN580715, EF113149)

R. etli CFN 42T (CP000133, EU488776, CP000133)

Rhizobium sp. I CCBAU 03409 (KM396582, KM396502, KM396472)

Rhizobium sp. V CCBAU 11560 (KM396604, KM396524, KM396492)

$R$. lusitanum $\mathrm{p} 1-7^{\mathrm{T}}$ (DQ431674, EF639841, DQ431671)

100 S fredii USDA 205' (AJ294379, AF169591, AJ294402)

Phyllobacterium sophorae CCBAU 03422 (KJ685941, KM396593, KM396513)

B. elkanii CCBAU 71314 (KM396606, KM396526, KM396500)

B. elkanii CCBAU 73331 (KM396612, KM396532, KM396501)

60 B. elkanii CCBAU 71325 (KM396609, KM396529, KM396497)

$54 \quad$ B. elkanii CCBAU 71342 (KM396610, KM396530, KM396499)

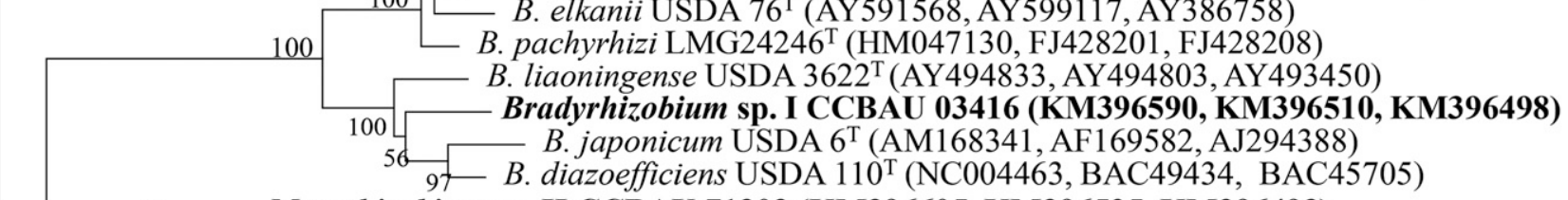

51_ Mesorhizobium sp. II CCBAU 71303 (KM396605, KM396525, KM396493)

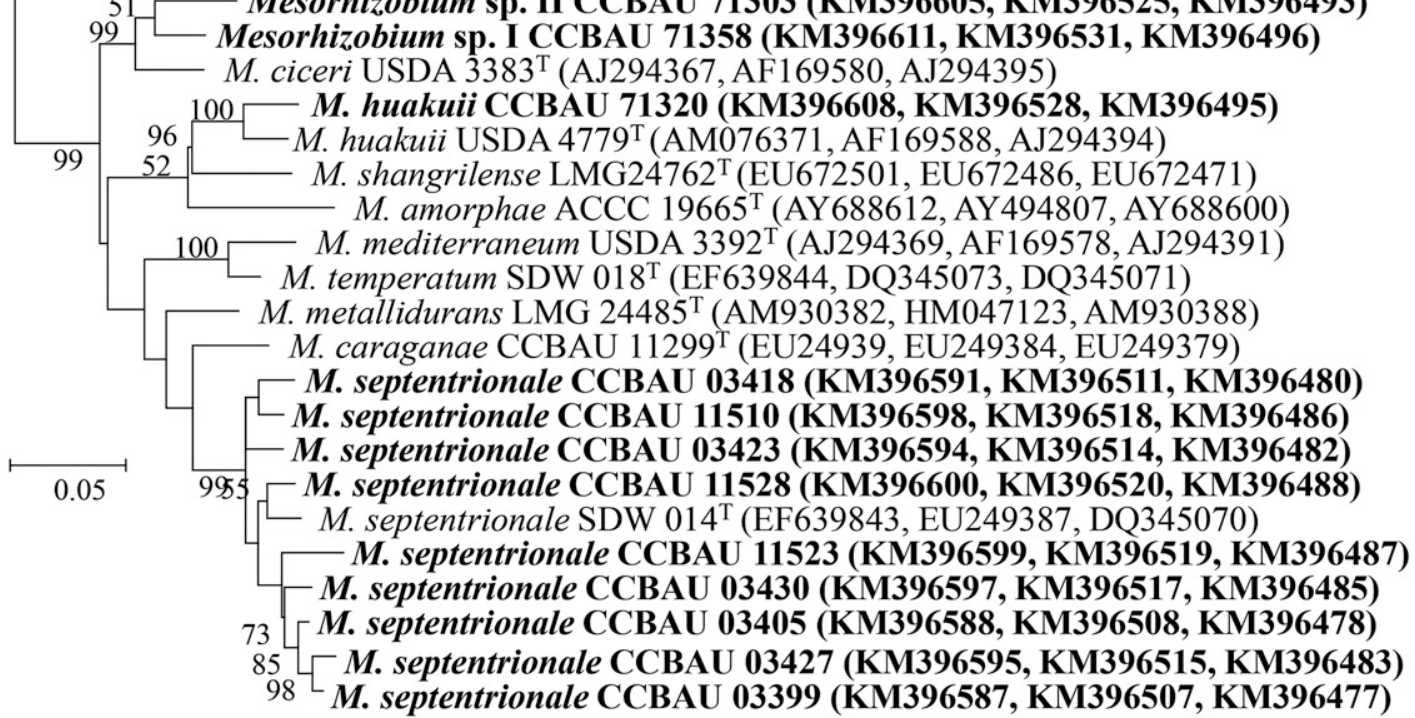

Fig. 1. Maximum likelihood phylogenetic tree based on the three concatenated genes (atpD-glnII-recA). The model GTR+G+I was used to construct the tree. Only bootstrap values greater than $50 \%$ are shown at branch nodes. Bar, 5\% nucleotide substitution per site. Boldfaced strains were isolated from Sophora flavescens. R., M., B., S., and P. = Rhizobium, Mesorhizobium, Bradyrhizobium, Sinorhizobium, and Phyllobacterium. T = type strain. 
these rhizobia $(P=0.0020)$ (Fig. 2 ; Table 1$). R$. yanglingense, $R$. mongolense, and Rhizobium sp. strain IV were solely found in alkaline soil at ecoregion III, while R. lusitanum, Mesorhizobium sp. strains I and II, M. huakuii, Bradyrhizobium elkanii were only found in acidic soil at ecoregion II.

\section{Diversity of symbiotic genes and cross nodulation.}

Excepting 3 isolates CCBAU 03429, CCBAU 03419 and CCBAU 71316 that failed to nodulate $S$. flavescens, the symbiotic genes nodC and nifH were amplified successfully from 266 isolates. As shown by the phylogenetic trees of $\operatorname{nod} C$ (Fig. 3) and nifH genes (Supplementary Fig. S2), the grouping results of $S$. flavescens isolates were similar and 7 symbiotic gene types $(\mathrm{I} \sim \mathrm{VII})$ were distinguishable. The nodC type I was found in all of the three ecoregions, including all of the isolates in genospecies $M$. septentrionale. Several isolates defined as $R$. mongolense, $M$. huakuii, Mesorhizobium sp. strain I and sp. strain II, had nodC genes identical or very similar to those of the reference strain M. septentrionale CCBAU 03074 that originated from Astragalus membranaceus. Type II included the isolates of Sinorhizobium fredii, M. septentrionale and $P$. sophorae from ecoregion I, which were identical or very similar to those of reference strains for Mesorhizobium species associated with Astragalus adsurgens, Glycyrrhiza pallidiflora and Caragana intermedia. Type III was composed of isolates belonging to Sinorhizobium fredii from ecoregion I, and they were identical to the reference strains in the same species that originated from soybean. Type IV was defined among the isolates of $R$. sophorae, $R$. sophoriradicis and Rhizobium sp. strain I from ecoregion I, whose symbiotic genes identical to those of some common bean (Phaseolus vulgaris)-nodulating rhizobia (bv. phaseoli). The nodC types V and VII were from the isolates of $R$. yanglingense, unique for ecoregion III, in which type $\mathrm{V}$ was similar to reference strains in the same species from Gueldenstaedtia multiflora/Medicago ruthenica while the type VII was a separated lineage. Type VI was specific for the isolates of B. elkanii from ecoregion II and their nodC and nifH genes were very similar to those of the soybean (Glycine max)nodulating strain (B. elkanii USDA $76^{\mathrm{T}}$ ) in the same species.

In the cross nodulation tests, 54 strains representing different species of the rhizobia in the classes of alpha-Proteobacteria $(\alpha$-rhizobia) and beta-Proteobacteria ( $\beta$-rhizobia) were selected to inoculate $S$. flavescens (Fig. 3 and Table 3). Most test strains, including the highly host-specific Rhizobium leguminosarum bv. viciae and $R$. etli bv. phaseoli, could effectively form nodules on $S$. flavescens. Another highly host-selective strain, R. leguminosarum bv. trifolii LMG $8820^{\mathrm{T}}$, could nodulate $S$. flavescens too, but the symbiosis were inefficient. The following 11 strains, Bradyrhizobium japonicum USDA $6^{\mathrm{T}}$, $B$. diazoefficiens USDA $110^{\mathrm{T}}$, B. yuanmingense CCBAU $10071^{\mathrm{T}}$, Bradyrhizobium $\mathrm{sp}$. strain ORS278, B. oligotrophicum LMG $10732^{\mathrm{T}}$, Ochrobactrum lupini LMG $22726^{\mathrm{T}}$, M. muleiense CCBAU $83963^{\mathrm{T}}$, M. amorphae

Table 2. Representative genospecies identified based on multilocus sequence analysis (MLSA) similarities and their distribution in each sampling site and ecoregion

\begin{tabular}{|c|c|c|c|c|c|c|c|c|c|c|c|c|c|c|c|c|c|c|c|c|}
\hline \multirow[b]{3}{*}{ CCBAU no. ${ }^{a}$} & \multirow[b]{3}{*}{ Genospecies $^{\mathbf{b}}$} & \multicolumn{19}{|c|}{ Number of isolates in different ecoregions and sites ${ }^{c}$} \\
\hline & & \multicolumn{11}{|c|}{ Ecoregion I $(n=105)$} & \multicolumn{4}{|c|}{ Ecoregion II $(n=81)$} & \multicolumn{3}{|c|}{$\begin{array}{l}\text { Ecoregion III } \\
\quad(n=83)\end{array}$} & \multirow[b]{2}{*}{ Total } \\
\hline & & S1 & S2 & $\mathbf{S 3}$ & S4 & S5 & S6 & S7 & S8 & S9 & S10 & S11 & S12 & S13 & S14 & S15 & S16 & S17 & S18 & \\
\hline 03470 & $\begin{array}{l}\text { R. sophoriradicis } \\
(100.0 \%)\end{array}$ & 2 & 2 & & 12 & & & & & & & & & & & & & & 4 & 20 \\
\hline 03386 & $\begin{array}{l}\text { R. sophorae } \\
(100.0 \%)\end{array}$ & & & & & 3 & 2 & & & & & 11 & & & & & 1 & 5 & 3 & 25 \\
\hline 03360 & $\begin{array}{l}\text { Rhizobium sp. } \\
\text { strain I (95.8\%) }\end{array}$ & 3 & & & 2 & 2 & & 2 & 1 & & & 2 & & & & & & & & 12 \\
\hline 03429 & $\begin{array}{l}\text { Rhizobium sp. } \\
\text { strain II (95.5\%) }\end{array}$ & & & & & 1 & & & & & & & & & & & & & & 1 \\
\hline 03419 & $\begin{array}{l}\text { Rhizobium sp. } \\
\text { strain III }(94.8 \%)\end{array}$ & & & & & 1 & & & & & & & & & & & & 2 & & 3 \\
\hline 11560 & $\begin{array}{l}\text { Rhizobium sp. } \\
\text { strain IV (94.5\%) }\end{array}$ & & & & & & & & & & & & & & & & & 1 & 1 & 2 \\
\hline 71316 & $\begin{array}{l}\text { R. lusitanum } \\
(99.5 \%)\end{array}$ & & & & & & & & & & & & & 2 & & & & & & 2 \\
\hline 11559 & $\begin{array}{l}\text { R. mongolense } \\
(96.0 \%)\end{array}$ & & & & & & & & & & & & & & & & 1 & 2 & 1 & 4 \\
\hline 11536 & $\begin{array}{l}\text { R. yanglingense } \\
(97.8 \%)\end{array}$ & & & & & & & & & & & & & & & & 27 & 1 & 1 & 29 \\
\hline 03373 & S. fredii $(99.2 \%)$ & & & 5 & 20 & & & 3 & 6 & 2 & 8 & 1 & & & & & & & 1 & 46 \\
\hline 71358 & $\begin{array}{l}\text { Mesorhizobium sp. } \\
\text { strain I (95.4\%) }\end{array}$ & & & & & & & & & & & & 1 & & & 28 & & & & 29 \\
\hline 71303 & $\begin{array}{r}\text { Mesorhizobium sp. } \\
\text { strain II (94.5\%) }\end{array}$ & & & & & & & & & & & & 2 & & & & & & & 2 \\
\hline 71320 & M. huakuii (96.4\%) & & & & & & & & & & & & 11 & 8 & & & & & & 19 \\
\hline 03405 & $\begin{array}{l}\text { M. septentrionale } \\
(97.1 \%)\end{array}$ & & & 1 & & 9 & 1 & & & & & & & & & & & 24 & 6 & 41 \\
\hline 71325 & B. elkanii $(96.5 \%)$ & & & & & & & & & & & & & 6 & 23 & & & & & 29 \\
\hline 03416 & $\begin{array}{c}\text { Bradyrhizobium sp. } \\
\text { strain I }(94.5 \%)\end{array}$ & & & & & 1 & & & & & & & & & & & & & & 1 \\
\hline \multirow[t]{2}{*}{03422} & P. sophorae $(100 \%)$ & & & & & 2 & & & & & & & & & & & & 2 & & 4 \\
\hline & Total & 5 & 2 & 6 & 34 & 19 & 3 & 5 & 7 & 2 & 8 & 14 & 14 & 16 & 23 & 28 & 29 & 37 & 17 & 269 \\
\hline \multirow[t]{3}{*}{$\begin{array}{l}\text { Diversity } \\
\text { indexes }\end{array}$} & $\begin{array}{l}\text { Shannon-Wiener } \\
\text { index }\left(H^{\prime}\right)\end{array}$ & 0.67 & 0.00 & 0.45 & 0.85 & 1.58 & 0.64 & 0.67 & 0.41 & 0.00 & 0.00 & 0.66 & 0.66 & 0.97 & 0.00 & 0.00 & 0.30 & 1.22 & 1.68 & 1 \\
\hline & Simpson index $(D)$ & 0.48 & 0.00 & 0.28 & 0.53 & 0.72 & 0.44 & 0.48 & 0.24 & 0.00 & 0.00 & 0.36 & 0.36 & 0.59 & 0.00 & 0.00 & 0.13 & 0.55 & 0.78 & I \\
\hline & Pielou index $(J)$ & 0.97 & Null & 0.65 & 0.77 & 0.81 & 0.92 & 0.97 & 0.59 & Null & Null & 0.60 & 0.60 & 0.89 & Null & Null & 0.27 & 0.63 & 0.86 & I \\
\hline
\end{tabular}


ATCC $19665^{\mathrm{T}}$, R. galegae HAMBI $1174^{\mathrm{T}}$, Burkholderia nodosa LMG $23741^{\mathrm{T}}$ and Burkholderia phymatum STM $815^{\mathrm{T}}$ could not infect S. flavescens (Fig. 3; Table 3). Sinorhizobium meliloti USDA $1002^{\mathrm{T}}$, CCBAU 01199, and 1021 could occasionally nodulate, but they fix nitrogen effectively on $S$. flavescens (Fig. 3; Table 3). The $\beta$-rhizobia Burkholderia sp. strain ICMP 19430 and ICMP 19869, Burkholderia tuberum LMG 21444 ${ }^{\mathrm{T}}$, and Cupriavidus taiwanensis LMG $19424^{\mathrm{T}}$ could nodulate $S$. flavescens, but the nitrogen fixation was inefficient and the nodules were white, small, and spherical, indicative of deficient function (Supplementary Figs. S4 and S7).

The isolates that originated from $S$. flavescens belonging to nodC types VI (B. elkanii CCBAU 71325 and CCBAU 71331), type IV ( $R$. sophorae CCBAU 03468, CCBAU 03386 and $R$. sophoriradicis CCBAU 03470), type II (M. septentrionale CCBAU 03399), and V (R. yanglingense CCBAU 11536) could nodulate effectively on Glycine max, Phaseolus vulgaris, Arachis hypogaca, Astragalus membranaceus, and Caragana intermedia, respectively (Table 3). While the isolates in types I (Mesorhizobium sp. strains I CCBAU 71358 and CCBAU 71303 and $M$. septentrionale CCBAU 03405) and II (P. sophorae CCBAU 03422) could not nodulate either Astragalus sinicus or A. membranaceus (Table 3).
Infection pattern, morphology, and efficiency of nodules.

Cellular curl, branch, or swell could be visible on the tips of root hairs of $S$. flavescens inoculated with the representative rhizobium (Sinorhizobium fredii CCBAU 45436 or $R$. yanglingense CCBAU 01603) under light-field microscopy (Fig. 4B through E). Aggregation on the bifurcating site, formation of the infection pocket or thread were observed clearly on and in the root hairs infected by lacZ-labeled rhizobia (strains CCBAU 45436 or CCBAU 01603) (Fig. 4F through H). Nodule primordium was found after 15 days of inoculation (Fig. 4I through J).

Most nodules were found on lateral roots and only a few on the taproots. Most reference strains and isolates (like M. septentrionale CCBAU 03399) formed effective nitrogenfixation nodules with red color in the nodule section, while reference strain $M$. huakuii 7653R formed low-efficiency nodules on the plants that showed yellowish leaves. Significant differences $(P<0.05)$ for chlorophyll content were observed between the plants inoculated with strains CCBAU 03399 and 7653R. Sphere-like and deficient nodules were formed by $\beta$-rhizobia of Burkholderia tuberum LMG $21444^{\mathrm{T}}$, Burkholderia spp. ICMP 19869 and ICMP 19430 (not shown), and Cupriavidus taiwanensis LMG $19424^{\mathrm{T}}$ on S. flavescens, while most $\alpha$-rhizobia formed effectively indeterminate

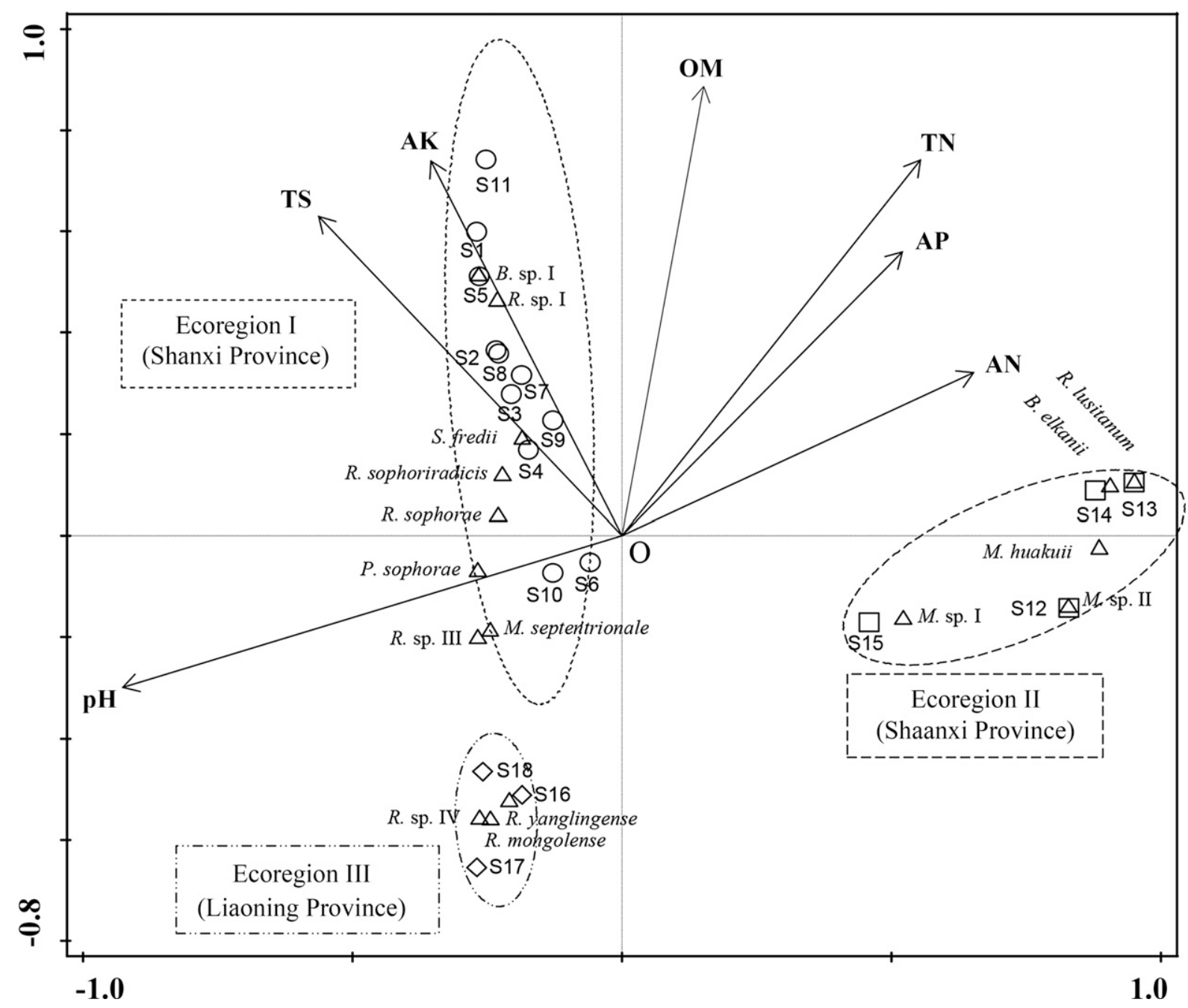

Fig. 2. Biplot showing relationships between the 17 genospecies and soil factors in three ecoregions, drawn using CANOCO software. AN $=$ available nitrogen, $\mathrm{AP}=$ available phosphorus, $\mathrm{AK}=$ available potassium, $\mathrm{OM}=$ organic materials, $\mathrm{TS}=$ total salt. The arrows and triangles show soil factors and genospecies, respectively. The circles $(\bigcirc)$, squares $(\square)$, and diamonds $(\diamond)$ show sampling sites in the three ecoregions I, II, and III. Triangles $(\triangle)$ show the distribution of genospecies. The longer the arrow is, the greater the influence the soil factor has on the distribution of the genospecies; the smaller the angle between the arrow and the line (not drawn) linking the triangle and original point $(\mathrm{O})$, the closer relationship the soil factor and the specific rhizobial genospecies have. 
(rod-shape or bifurcated) nodules on S. flavescens. Different parts showing the growth of the infection, nitrogen-fixation, and senescence zones were observed clearly in the section of effective nodules induced by $\alpha$-rhizobium $M$. septentrionale CCBAU 03399 (Supplementary Fig. S5). The root nodules formed by $\beta$-rhizobia were much smaller (about $2 \mathrm{~mm}$ in diameter) than those formed by $\alpha$-rhizobia. No more than half of the plant cells within a nodule were infected by $\beta$-rhizobium (e.g., Burkholderia tuberum $\mathrm{LMG} 21444^{\mathrm{T}}$ ), while most of the plant cells within a nodule were full of $\alpha$-rhizobium (e.g., M. septentrionale CCBAU 03399). Yellowish leaves of the plants inoculated with $\beta$-rhizobia were visualized and chlorophyll content of the leaves was only 23 to $25 \mu \mathrm{g} / \mathrm{cm}^{2}$ (SPAD 502), lower than in the $\alpha$-rhizobia-inoculated plants (approximately $30 \mu \mathrm{g} / \mathrm{cm}^{2}$ ).

\section{Bacteroids in the nodules.}

Observation of mature nodules (35 days old) through electron microscopy indicated that the bacteroids in nodule cells of $S$. flavescens were regular or irregular rods with lengths $<3 \mu \mathrm{m}$ and widths $<1.6 \mu \mathrm{m}$ (Fig. 5; Supplementary Fig. S6). Some rhizobia, such as Sinorhizobium sp. strain NGR 234, B. elkanii $\mathrm{USDA76}^{\mathrm{T}}$, and Sinorhizobium meliloti CCBAU 01199, synthesized large amounts of poly- $\beta$-hydroxybutyrate (PHB) inside the bacteroids; while other strains, like M. loti NZP $2213^{\mathrm{T}}$, M. septentrionale CCBAU 03399, and B. arachidis CCBAU $051107^{\mathrm{T}}$ only synthesized a few PHB granules (Fig. 5). One to 10 bacteroids could be embedded in a peribacteroid membrane (PBM) inside a host plant cell (Fig. 5). Some bacteroids inside the intercellular walls were not embedded in PBM and, therefore, had a free existence (Fig. 5D, E and F). The volume of peribacteroid space (PBS) varied in nodules induced by different rhizobia on S. flavescens. The bacteroids of Mesorhizobium loti NZP $2213^{\mathrm{T}}$ presented an intracellular membrane system (Fig. $5 \mathrm{H})$. Only a few bacteroids were found in the ineffective nodules formed by $\beta$-rhizobium Burkholderia tuberum LMG $21444^{\mathrm{T}}$, which existed singly (Fig. 5I) and were accompanied by starch grains inside the nodule cells (Fig. 5I). In addition, incomplete PBM surrounding the bacteroids was observed in some Burkholderia-induced nodules (Fig. 5J).

\section{DISCUSSION}

\section{Diversity of rhizobia nodulating Sophora flavescens.}

In the present study, rhizobial diversity and nodule characteristics of $S$. flavescens were thoroughly studied. The identification of 17 genospecies belonging to five genera (Table 2) with seven very different nodC types (Fig. 3) among the nodule isolates indicated that this plant has a less stringent requirement for either the genomic backgrounds or the symbiotic gene backgrounds of the rhizobia, which suggested a third group of legumes, in addition to the two groups classified by Laguerre et al. (2003), i.e., legumes strongly selected for both the genomic background and symbiotic background and legumes that strongly preferred the symbiotic gene background but not the genomic background. All the $S$. flavescens-nodulating rhizobia, no matter their hosts of origin, showed the existence of nodC, suggesting that symbiosis between this plant and the rhizobia is a nod factor-dependent procedure, similar to most of the other legumes found so far (Madsen et al. 2010).

Previously common bean (Phaseolus vulgaris) has been believed to be one of the most promiscuous hosts for rhizobia (Dall'Agnol et al. 2014; Verástegui-Valdés et al. 2014), which nodulated with 16 rhizobial species in genera Rhizobium and Sinorhizobium, but all the bean-nodulating rhizobia harbored very similar symbiotic genes, even biovars phaseoli and mediterraneum were differentiated (Verástegui-Valdés et al. 2014). The other promiscuous hosts were members of genus Acacia, which can establish symbiosis with several species in genera Mesorhizobium and Sinorhizobium (Ba et al. 2002) and Siratro (Macroptilium atropurpureum), which is often used to test the capability of nodulation of different rhizobia (Angus et al. 2013; Moulin et al. 2001). Recently, Sophora alopecuroides was reported as a promiscuous host for 10 rhizobial species in the genera Bradyrhizobium, Sinorhizobium, Mesorhizobium, and Phyllobacterium, with five divergent types of symbiotic genes (Zhao et al. 2010). In addition, Han et al. (2008) identified three strains isolated from $S$. alopecuroides as $B$. elkanii and $R$. tropici-related genospecies. Compared with the three legumes mentioned above, the rhizobia of $S$. flavescens showed the following differences. The first remarkable difference was that $S$. flavescens presented a much larger promiscuous property by nodulating with rhizobia in 17 genospecies of five genera in the fields (Table 2) and with 20 more species originated from other legume species in laboratory conditions (Table 3). The second difference was that the rhizobial community composition of $S$. flavescens was uniquely characterized by nine major groups in genera Sinorhizobium, Mesorhizobium, Bradyrhizobium, and Rhizobium as well as eight minor groups in genera Phyllobacterium, Bradyrhizobium, Mesorhizobium, and Rhizobium, including seven putative novel species (Table 2; Fig. 1). These results differentiated $S$. flavescens clearly from S. alopecuroides, common bean, and Acacia spp. for their different rhizobial composition.

\section{Geographic patterns of $S$. flavescens rhizobia.}

Geographic patterns have been observed previously in rhizobia associated with Caragana spp. (Lu et al. 2009) and with soybean (Zhang et al. 2011). This pattern is also observed in the rhizobia associated with $S$. flavescens (Table 2; Supplementary Fig. S1). Soil factors were revealed as determinants for the distribution and community composition of rhizobia (Fig. 2), similar to previous results (Lu et al. 2009; Zhang et al. 2011). The distribution of Sinorhizobium fredii mainly in ecoregion I (Table 2) demonstrated its adaptation to high-salinity soils (Table 1), which is similar to the previous study on soybean rhizobia (Han et al. 2009; Li et al. 2011; Zhang et al. 2011). The limited distribution of B. elkanii to ecoregion II evidenced its adaptation to acid soils (Table 2), which is also similar to previous observations for soybean rhizobia (Li et al. 2011; Zhang et al. 2011). Previously, Weir et al. (2004) and Tan et al. (2015) found that Sophora spp. in New Zealand nodulated with Rhizobium leguminosarum, Mesorhizobium loti, and other Mesorhizobium species. According to the results in the current study as well as others, it is clear that the Sophora species, especially $S$. flavescens, preferred different rhizobial species in different soils. The capability of nodulation with extremely diverse rhizobia offered S. flavescens a wide range of microsymbionts for selection and help in adapting to various environments.

\section{Evolution of symbiotic genes and nodulation of S. flavescens.}

The phylogenetic relationships in the nodC gene tree (Fig. 3) and the nifH gene tree in the present study demonstrated a coevolution of the nodulation genes and the nitrogen-fixation genes in the $S$. flavescens-nodulating rhizobia. Previously, it has been estimated that the biogeographic patterns of rhizobia are determined by their adaptation to soil environments and the selection of host legumes for the rhizobial genospecies and symbiotic genes (Zhang et al. 2012; Zheng et al. 2013). But the symbiotic genes in rhizobia associated with Glycine max (Zhang et al. 2012), S. alopecuroides (Zhao et al. 2010), and S. flavescens involved in the present study (Fig. 3) were diverse, indicating that the specific selection of the symbiotic genes was not stringent for these plant species. This estimation was further 


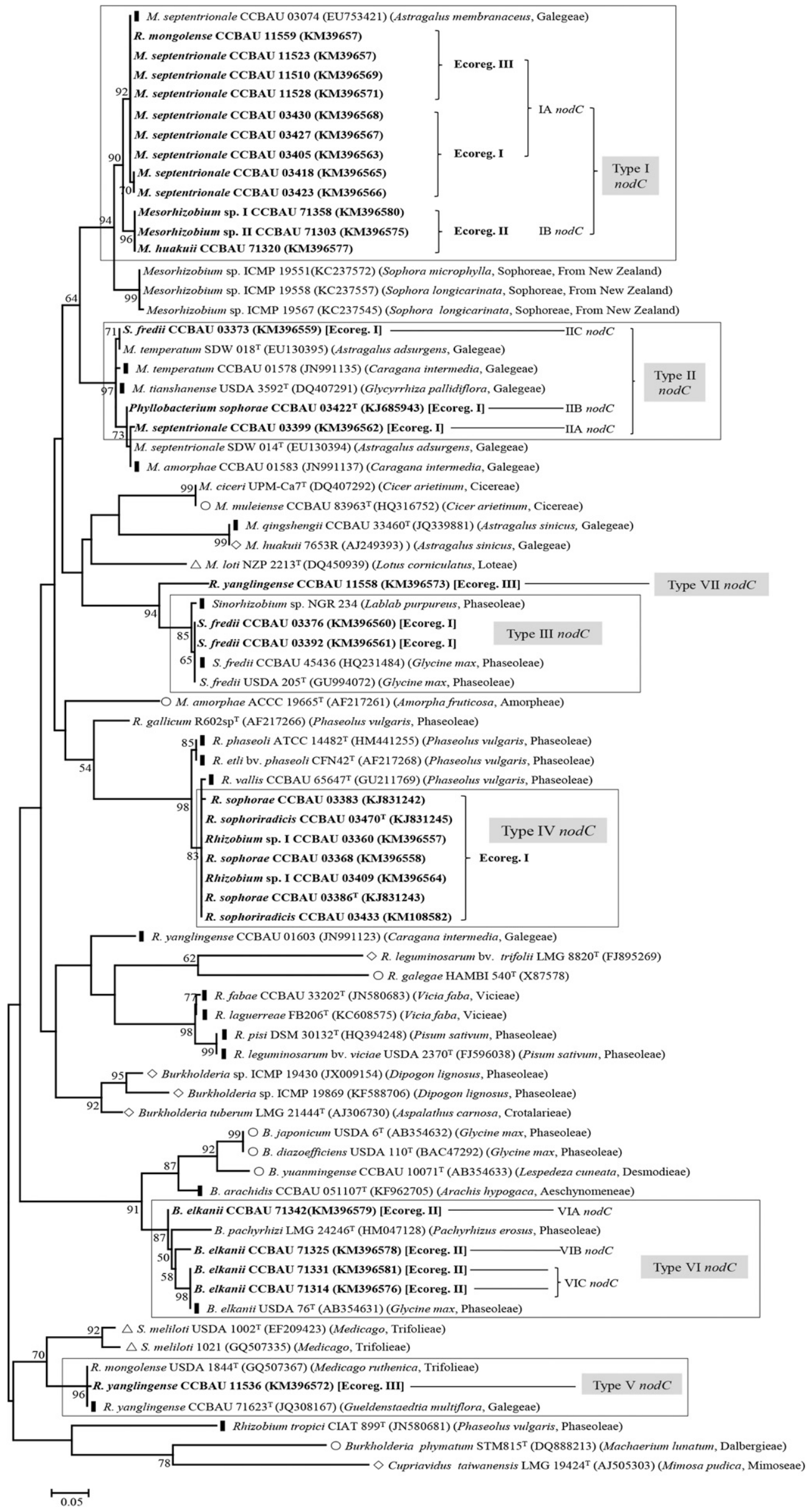


supported by the fact that many rhizobial strains harbored diverse symbiotic genes and originated from distinct legumes in the tribes Galegeae, Phaseoleae, Vicieae, Crotalarieae, Trifolieae, Mimoseae, and Aeschynomeneae could nodulate with $S$. flavescens under laboratory conditions (Fig. 3; Table 3). These results demonstrated that the biogeographic patterns of the $S$. flavescens-nodulating rhizobia may be mainly determined by environmental adaptation and less affected by the selection of symbiotic gene background by the host plant. Further surveys are needed to clarify the mechanism for this phenomenon.

Only the nodC types represented by the Cicer-nodulating strains Mesorhizobium ciceri UPM-Ca $7^{\mathrm{T}}$ and $M$. muleiense CCBAU $83963^{\mathrm{T}}$, Amorpha-nodulating strain M. amorphae ACCC $19665^{\mathrm{T}}$, soybean-nodulating strains $B$. japonicum USDA $6^{\mathrm{T}}$, B. diazoefficiens USDA $110^{\mathrm{T}}$, and Lespedeza-nodulating strain B. yuanmingense CCBAU $10071^{\mathrm{T}}$ could not nodulate $S$. flavescens in the cross-nodulation tests. Therefore, the phylogenetic relationships of nodC could not accurately reflect the host specificity of rhizobia in some cases, although Laguerre et al. (2001) used this relationship to estimate the host range for rhizobia. It is interesting that the soybean-nodulating strains Sinorhizobium fredii CCBAU 45436 (nodC type III) and B. elkanii USDA $76^{\mathrm{T}}$ (nodC type VI) could nodulate $S$. flavescens efficiently, but $B$. japonicum USDA $6^{\mathrm{T}}$ and $B$. diazoefficiens USDA $110^{\mathrm{T}}$ (belonging to a distinct nodC type) could not. In another case, the strains $M$. qingshengii CCBAU $33460^{\mathrm{T}}$ and M. huakuii 7653R originated from Astragalus sinicus and harbored identical nodC genes, but the former could nodulate with $S$. flavescens effectively while the latter one formed less-efficient nodules. These cases demonstrate that other genes might also affect the nodulation preference of $S$. flavescens.

In the present study, four $\beta$-rhizobial strains belonging to genera Burkholderia and Cupriavidus formed inefficient nodules (Fig. $5)$, demonstrating that the affinity between the $\beta$-rhizobia and $S$. flavescens has not been well developed. The Burkholderia spp. may be more related in their adaptation to infertile, acidic soils and in their symbioses with legumes that are similarly adapted to these climatic and edaphic conditions (Garau et al. 2009). More $\beta$-rhizobia need to be surveyed for nodulation efficiency with $S$. flavescens in different soil conditions in the future.

The discordance between the phylogenetic tree for nodC (Fig. 3) and the phylogenetic tree inferred from MLSA (Fig. 1) implies that lateral transfer of the symbiotic genes might have happened across some strains and species, such as between M. temperatum SDW $018^{\mathrm{T}}$ and Sinorhizobium fredii CCBAU 03373, M. septentrionale SDW $014^{\mathrm{T}}$ and $P$. sophorae CCBAU $03422^{\mathrm{T}}$, among $R$. sophoriradicis CCBAU $03470^{\mathrm{T}}, R$. sophorae CCBAU $03386^{\mathrm{T}}$, and $R$. vallis CCBAU $65647^{\mathrm{T}}$, and among Mesorhizobium sp. strain I CCBAU 71358, Mesorhizobium sp. strain II CCBAU 71303, and M. huakuii CCBAU 71320 (Fig. 3). The existence of lateral gene transfer of nodC among different rhizobia may be another reason that $S$. flavescens could nodulate with such diverse rhizobia.

Although diverse rhizobia with different symbiotic gene types were detected in the microsymbionts of $S$. flavescens, the presence and relative predominance of nodC type I in all three ecoregions as well as their high similarity to that of three Mesorhizobium strains (with representative isolates of ICMP 19551, ICMP 19558, and ICMP 19567 originating from Sophora spp. grown in New
Zealand [Tan et al. 2015]) implies that type I nodC is the preferable symbiotic genotype for $S$. flavescens. The failure of cross nodulation of the representative strains in the branch of nodC type I (CCBAU 03405, CCBAU 71320, CCBAU 71358, and CCBAU 71303) on Astragalus membranaceus, A. sinicus, and Caragana intermedia (Table 3 ) further supports the fact that there are distinctly symbiotic genotypes held by these strains.

Infection pattern and nodule morphology of S. flavescens.

Previous reports have shown the relationship between the rhizobial spectrum of legume species and the infection mechanisms (Liu et al. 2014; Madsen et al. 2010; Op den Camp et al. 2012; Sajnaga et al. 2001). In our current study, only root-hair infection (RHI) was clearly observed on S. flavescens (Fig. 4). Considering the results of the promiscuous associations of soybean and common bean (both are RHI patterns), it is possible that the diversity of rhizobia associated with a legume is not related to the infection pattern but to the other determinants (Yang et al. 2010).

Generally, nodules of legumes can be classified as indeterminate and determinate forms depending on the persistent or transient apical distribution of nodule meristem (Sprent 2009). Indeterminate nodules are more common in legumes, but all the examined members of the tribes Desmodieae, Phaseoleae, and Psoraleae and some members of the Loteae produce determinate nodules. Two legume species, Sesbania rostrata (FernándezLópez et al. 1998) and Dipogon lignosus (Liu et al. 2014), were capable of forming both indeterminate and determinate nodules. In the present study, root nodules of $S$. florescence formed by $\alpha$-rhizobia were indeterminate and no determinate nodules were observed. In addition, the fact that strain Bradyrhizobium arachidis CCBAU $051107^{\mathrm{T}}$ originated from peanut (Wang et al. 2013), induced determinate nodules on peanut and indeterminate nodules on $S$. flavescens further confirmed the control of nodule morphology by host plants.

\section{Bacteroids inside the nodule cells of $S$. flavescens.}

In contrast to the relatively low bacteroid counts in the symbiosome of soybean (Margaret et al. 2013) and Astragalus sinicus (Lei et al. 2014), S. flavescens can contain 10 or more bacteroids in a single symbiosome in the effective nodules. This might imply that bacterial division inside the S. flavescens symbiosomes was not well controlled. Future studies will be focused on determining if this phenomenon is related to a wide spectrum of microsymbionts.

Spherical and swollen large bacteroids were observed in peanut nodules (Bal et al. 1985; Okubo et al. 2012; Oono and Denison 2010), but Bradyrhizobium arachidis CCBAU $051107^{\mathrm{T}}$, a strain originated from peanut (Wang et al. 2013), presented only nonswollen bacteroids in nodules of S. flavescens (Fig. 5F). In addition, all other bacteroids in nodules formed by different rhizobia on S. flavescens were nonswollen. This finding provides further evidence that the differentiation of bacteroids into swollen or nonswollen types is determined by the host plant (Oono and Denison 2010).

Most PBS formed by Mesorhizobium loti NZP $2231^{\mathrm{T}}$ is limited by the PBM and the bacteroids being in close contact (Fig. 5), while the PBS formed by $M$. septentrionale CCBAU 03399, Sinorhizobium sp. strain NGR 234, and B. arachidis

Fig. 3. Maximum likelihood phylogenetic tree based on nodC genes. The model T92+G+I was used to construct the tree. Only bootstrap values greater than $50 \%$ are shown at branch nodes. Bar, $5 \%$ nucleotide substitution per site. A thick vertical bar indicates effective nodules; circles $(\bigcirc)$, no nodule; triangles $(\triangle)$, not stable, but effective nodules; and diamonds $(\diamond)$, less-effective or inefficient nodules. The strains with boldfaced names were isolated from Sophora flavescens. Host plants of origin of these rhizobia were added after the accession number of each strain. Ecoreg. $=$ ecoregion, $R .=$ Rhizobium, B. $=$ Bradyrhizobium, . $=$ Sinorhizobium, $M .=$ Mesorhizobium, and $\mathrm{T}=$ type strain. 


\begin{tabular}{|c|c|c|c|c|c|c|c|c|c|c|c|c|c|c|c|}
\hline \multirow[b]{2}{*}{ Strains (nodC type) } & \multirow[b]{2}{*}{ Original host (tribe) } & \multicolumn{2}{|c|}{$\begin{array}{c}\text { Sophora } \\
\text { flavescens }\end{array}$} & \multicolumn{2}{|c|}{$\begin{array}{c}\text { Caragana } \\
\text { intermedia }\end{array}$} & \multicolumn{2}{|c|}{$\begin{array}{c}\text { Astragalus } \\
\text { membranaceus }\end{array}$} & \multicolumn{2}{|c|}{$\begin{array}{c}\text { Astragalus } \\
\text { sinicus }\end{array}$} & \multicolumn{2}{|c|}{$\begin{array}{l}\text { Glycine } \\
\max \end{array}$} & \multicolumn{2}{|c|}{$\begin{array}{c}\text { Phaseolus } \\
\text { vulgaris }\end{array}$} & \multicolumn{2}{|c|}{$\begin{array}{c}\text { Arachis } \\
\text { hypogaca }\end{array}$} \\
\hline & & Nod & Nif & Nod & Nif & Nod & Nif & Nod & Nif & Nod & Nif & Nod & Nif & Nod & Nif \\
\hline \multicolumn{16}{|l|}{ Bradyrhizobium $\mathrm{spp}_{\tau}$} \\
\hline $\begin{array}{l}\text { elkanii CCBAU } 71325 \\
\text { (VIB) }\end{array}$ & $\begin{array}{l}\text { Sophora flavescens } \\
\text { (Sophoreae) }\end{array}$ & $\mathrm{o}$ & $\mathrm{O}$ & & & & & & & + & $\mathrm{F}$ & & & & \\
\hline $\begin{array}{l}\text { elkanii CCBAU } 71331 \\
\text { (VIC) }\end{array}$ & $\begin{array}{l}\text { Sophora flavescens } \\
\text { (Sophoreae) }\end{array}$ & $\mathrm{o}$ & $\mathrm{O}$ & & & & & & & + & $\mathrm{F}$ & & & & \\
\hline diazoefficiens USDA $110^{\mathrm{T}}$ & Glycine max (Pasesoleae) & - & & & & & & & & $\mathrm{O}$ & $\mathrm{O}$ & & & & \\
\hline japonicum USDA $6^{\mathrm{T}}$ & Glycine max (Pasesoleae) & - & & & & & & & & $\mathrm{O}$ & $\mathrm{O}$ & & & & \\
\hline liaoningense LMG $18320^{\mathrm{T}}$ & Glycine max (Pasesoleae) & - & & & & & & & & & & & & & \\
\hline arachidis $\mathrm{CCBAU} 051107^{\mathrm{T}}$ & $\begin{array}{l}\text { Arachis hypogaea } \\
\text { (Aeschynomeneae) }\end{array}$ & + & $\mathrm{F}$ & & & & & & & & & & & $\mathrm{O}$ & $\mathrm{O}$ \\
\hline $\begin{array}{l}\text { yuanmingense CCBAU } \\
10071^{\mathrm{T}}\end{array}$ & $\begin{array}{l}\text { Lespedeza cuneata } \\
\text { (Desmodieae) }\end{array}$ & - & & & & & & & & & & & & & \\
\hline $\begin{array}{l}\text { oligotrophicum LMG } \\
10732^{\mathrm{T}}\end{array}$ & $\begin{array}{l}\text { Soil, symbiosis with } \\
\text { Aeschynomene indica }\end{array}$ & - & & & & & & & & & & & & & \\
\hline sp. strain ORS278 & $\begin{array}{l}\text { Aeschynomene sensitive } \\
\text { (Aeschynomeneae) }\end{array}$ & - & & & & & & & & & & & & & \\
\hline Rhizobium spp. & & & & & & & & & & & & & & & \\
\hline $\begin{array}{l}\text { yanglingense CCBAU } \\
01603\end{array}$ & $\begin{array}{l}\text { Caragana intermedia } \\
\text { (Galegeae) }\end{array}$ & + & $\mathrm{F}$ & $\mathrm{O}$ & $\mathrm{O}$ & & & & & & & & & & \\
\hline $\begin{array}{l}\text { yanglingense CCBAU } \\
\quad 71623^{\mathrm{T}}\end{array}$ & $\begin{array}{l}\text { Gueldenstaedtia multiflora } \\
\text { (Galegeae) }\end{array}$ & + & $\mathrm{F}$ & & & & & & & & & & & & \\
\hline fabae $\mathrm{CCBAU} 33202^{\mathrm{T}}$ & Vicia faba (Vicieae) & + & $\mathrm{F}$ & & & & & & & & & & & & \\
\hline $\begin{array}{l}\text { leguminosarum bv. viciae } \\
\text { USDA } 2370^{T}\end{array}$ & Pisum sativum (Pasesoleae) & + & $\mathrm{F}$ & & & & & & & & & & & & \\
\hline galegae HAMI $540^{\mathrm{T}}$ & Galega orientalis (Galegeae) & - & & & & & & & & & & & & & \\
\hline tropici CIAT $899^{\mathrm{T}}$ & $\begin{array}{l}\text { Phaseolus vulgaris } \\
\text { (Pasesoleae) }\end{array}$ & + & $\mathrm{F}$ & & & & & & & & & $\mathrm{O}$ & $\mathrm{O}$ & & \\
\hline pisi DSM $30132^{\mathrm{T}}$ & Pisum sativum (Pasesoleae) & + & $\mathrm{F}$ & & & & & & & & & & & & \\
\hline laguerreae $\mathrm{FB} 206^{\mathrm{T}}$ & Vicia faba (Vicieae) & + & $\mathrm{F}$ & & & & & & & & & & & & \\
\hline vallis $\mathrm{CCBAU} 65647^{\mathrm{T}}$ & $\begin{array}{l}\text { Phaseolus vulgaris } \\
\text { (Pasesoleae) }\end{array}$ & + & $\mathrm{F}$ & & & & & & & & & $\mathrm{O}$ & $\mathrm{O}$ & & \\
\hline phaseoli ATCC $14482^{\mathrm{T}}$ & $\begin{array}{l}\text { Phaseolus vulgaris } \\
\text { (Pasesoleae) }\end{array}$ & + & $\mathrm{F}$ & & & & & & & & & $\mathrm{O}$ & $\mathrm{O}$ & & \\
\hline etli bv. phaseoli $\mathrm{CFN} 42^{\mathrm{T}}$ & $\begin{array}{l}\text { Phaseolus vulgaris } \\
\text { (Pasesoleae) }\end{array}$ & + & $\mathrm{F}$ & & & & & & & & & $\mathrm{O}$ & $\mathrm{O}$ & & \\
\hline $\begin{array}{l}\text { leguminosarum bv. trifolii } \\
\text { LMG } 8820^{\mathrm{T}}\end{array}$ & Trifolium pratense (Trifolieae) & + & $\diamond$ & & & & & & & & & & & & \\
\hline $\begin{array}{l}\text { sophorae CCBAU } 03468 \\
\text { (IV) }\end{array}$ & $\begin{array}{l}\text { Sophora flavescens } \\
\text { (Sophoreae) }\end{array}$ & $\mathrm{O}$ & $\mathrm{O}$ & & & & & & & & & + & $\mathrm{F}$ & & \\
\hline $\begin{array}{l}\text { sophorae CCBAU } 03386 \\
\text { (IV) }\end{array}$ & $\begin{array}{l}\text { Sophora flavescens } \\
\text { (Sophoreae) }\end{array}$ & $\mathrm{o}$ & $\mathrm{o}$ & & & & & & & & & + & $\mathrm{F}$ & & \\
\hline $\begin{array}{l}\text { sophoriradicis CCBAU } \\
03470 \text { (IV) }\end{array}$ & $\begin{array}{l}\text { Sophora flavescens } \\
\text { (Sophoreae) }\end{array}$ & $\mathrm{O}$ & $\mathrm{O}$ & & & & & & & & & + & $\mathrm{F}$ & & \\
\hline $\begin{array}{l}\text { yanglingense CCBAU } \\
11536(\mathrm{~V})\end{array}$ & $\begin{array}{l}\text { Sophora flavescens } \\
\quad \text { (Sophoreae) }\end{array}$ & $\mathrm{o}$ & $\mathrm{O}$ & + & $\mathrm{F}$ & & & & & & & & & & \\
\hline Sinorhizobium spp. & & & & & & & & & & & & & & & \\
\hline meliloti USDA $1002^{\mathrm{T}}$ & Medicago sativa (Trifolieae) & \pm & $\mathrm{F}$ & & & & & & & & & & & & \\
\hline meliloti 1021 & Medicago sativa (Trifolieae) & \pm & $\mathrm{F}$ & & & & & & & & & & & & \\
\hline meliloti CCBAU 01199 & Medicago sativa (Trifolieae) & \pm & $\mathrm{F}$ & & & & & & & & & & & & \\
\hline sp. strain NGR 234 & Lablab purpureus (Pasesoleae) & + & $\mathrm{F}$ & & & & & & & & & & & & \\
\hline fredii CCBAU 45436 & Glycine max (Pasesoleae) & + & $\mathrm{F}$ & & & & & & & $\mathrm{O}$ & $\mathrm{O}$ & & & & \\
\hline fredii CCBAU 03392 (III) & $\begin{array}{l}\text { Sophora flavescens } \\
\quad \text { (Sophoreae) }\end{array}$ & $\mathrm{O}$ & $\mathrm{O}$ & & & & & & & + & $\mathrm{F}$ & & & & \\
\hline Mesorhizobium spp. & & & & & & & & & & & & & & & \\
\hline loti NZP $2213^{\mathrm{T}^{1}}$ & Lotus corniculatus (Loteae) & + & $\mathrm{F}$ & & & & & & & & & & & & \\
\hline muleiense CCBAU $83963^{\mathrm{T}}$ & Cicer arietinum (Cicereae) & - & & & & & & & & & & & & & \\
\hline huakuii CCBAU $2609^{\mathrm{T}}$ & Astragalus sinicus (Galegeae) & - & & & & & & $\mathrm{O}^{\mathrm{b}}$ & & & & & & & \\
\hline huakuii $7653 \mathrm{R}$ & Astragalus sinicus (Galegeae) & + & $\diamond$ & & & & & $\mathrm{O}$ & $\mathrm{o}$ & & & & & & \\
\hline qingshengii $\mathrm{CCBAU} 33460^{\mathrm{T}}$ & Astragalus sinicus (Galegeae) & + & $\mathrm{F}$ & & & & & $\mathrm{O}$ & $\mathrm{O}$ & & & & & & \\
\hline amorphae ACCC $19665^{\mathrm{T}}$ & $\begin{array}{l}\text { Amorpha fruticosa } \\
\text { (Amorpheae) }\end{array}$ & - & & & & & & & & & & & & & \\
\hline tianshanense USDA $3592^{\mathrm{T}}$ & $\begin{array}{l}\text { Glycyrrhiza pallidiflora } \\
\text { (Galegeae) }\end{array}$ & + & $\mathrm{F}$ & & & & & & & & & & & & \\
\hline temperatum CCBAU 01578 & $\begin{array}{l}\text { Caragana intermedia } \\
\text { (Galegeae) }\end{array}$ & + & $\mathrm{F}$ & $\mathrm{O}$ & $\mathrm{O}$ & & & & & & & & & & \\
\hline amorphae CCBAU 01583 & $\begin{array}{l}\text { Caragana intermedia } \\
\text { (Galegeae) }\end{array}$ & + & $\mathrm{F}$ & $\mathrm{O}$ & $\mathrm{O}$ & & & & & & & & & & \\
\hline $\begin{array}{l}\text { septentrionale CCBAU } \\
03074\end{array}$ & $\begin{array}{l}\text { Astragalus membranaceus } \\
\text { (Galegeae) }\end{array}$ & + & $\mathrm{F}$ & & & $\mathrm{o}$ & $\mathrm{O}$ & & & & & & & & \\
\hline $\begin{array}{l}\text { septentrionale CCBAU } \\
03399 \text { (IIA) }\end{array}$ & $\begin{array}{l}\text { Sophora flavescens } \\
\text { (Sophoreae) }\end{array}$ & $\mathrm{O}$ & $\mathrm{o}$ & + & $\mathrm{F}$ & + & $\mathrm{F}$ & - & & & & & & & \\
\hline $\begin{array}{l}\text { amorphae CCBAU } 03405 \\
\text { (IA) }\end{array}$ & $\begin{array}{l}\text { Sophora flavescens } \\
\text { (Sophoreae) }\end{array}$ & $\mathrm{O}$ & $\mathrm{o}$ & - & & - & & - & & & & & & & \\
\hline huakuii CCBAU 71320 (IB) & $\begin{array}{l}\text { Sophora flavescens } \\
\text { (Sophoreae) }\end{array}$ & $\mathrm{O}$ & $\mathrm{O}$ & - & & - & & - & & & & & & & \\
\hline $\begin{array}{l}\text { sp. strain I CCBAU } 71358 \\
\text { (IB) }\end{array}$ & $\begin{array}{l}\text { Sophora flavescens } \\
\text { (Sophoreae) }\end{array}$ & $\mathrm{O}$ & $\mathrm{O}$ & - & & - & & - & & & & & & & \\
\hline $\begin{array}{l}\text { sp. strain II CCBAU } 71303 \\
\text { (IB) }\end{array}$ & $\begin{array}{l}\text { Sophora flavescens } \\
\text { (Sophoreae) }\end{array}$ & $\mathrm{O}$ & $\mathrm{O}$ & - & & - & & - & & & & & & & \\
\hline $\begin{array}{l}\text { Ochrobactrum sp. } \\
\text { lupini LMG } 22726^{\mathrm{T}}\end{array}$ & Lupinus albus (Lupininae) & - & & & & & & & & & & & & & \\
\hline $\begin{array}{l}\text { Phyllobacterium sp. } \\
\text {. }\end{array}$ & & & & & & & & & & & & & & & \\
\hline $\begin{array}{l}\text { sophorae CCBAU } 03422^{\mathrm{T}} \\
\text { (IIB) }\end{array}$ & $\begin{array}{l}\text { Sophora flavescens } \\
\text { (Sophoreae) }\end{array}$ & $\mathrm{o}$ & $\mathrm{O}$ & - & & - & & - & & & & & & & \\
\hline Burkholderia spp. & & & & & & & & & & & & & & & \\
\hline tuberum LMG $21444^{\mathrm{T}}$ & $\begin{array}{l}\text { Aspalathus carnosa } \\
\text { (Crotalarieae) }\end{array}$ & + & $\diamond$ & & & & & & & & & & & & \\
\hline sp. strain ICMP 19869 & $\begin{array}{l}\text { Dipogon lignosus } \\
\quad \text { (Phaseoleae) }\end{array}$ & + & $\diamond$ & & & & & & & & & & & & \\
\hline nodosa $\mathrm{LMG} 23741^{\mathrm{T}}$ & Mimosa scabrella (Mimoseae) & - & & & & & & & & & & & & & \\
\hline phymatum STM815 & $\begin{array}{l}\text { Machaerium lunatum } \\
\text { (Dalbergieae) }\end{array}$ & - & & & & & & & & & & & & & \\
\hline sp. strain ICMP 19430 & $\begin{array}{l}\text { Dipogon lignosus } \\
\text { (Phaseoleae) }\end{array}$ & + & $\diamond$ & & & & & & & & & & & & \\
\hline $\begin{array}{l}\text { Cupriavidus sp. } \\
\quad \text { taiwanensis } \text { LMG } 19424^{\mathrm{T}}\end{array}$ & Mimosa pudica (Mimoseae) & + & $\diamond$ & & & & & & & & & & & & \\
\hline
\end{tabular}



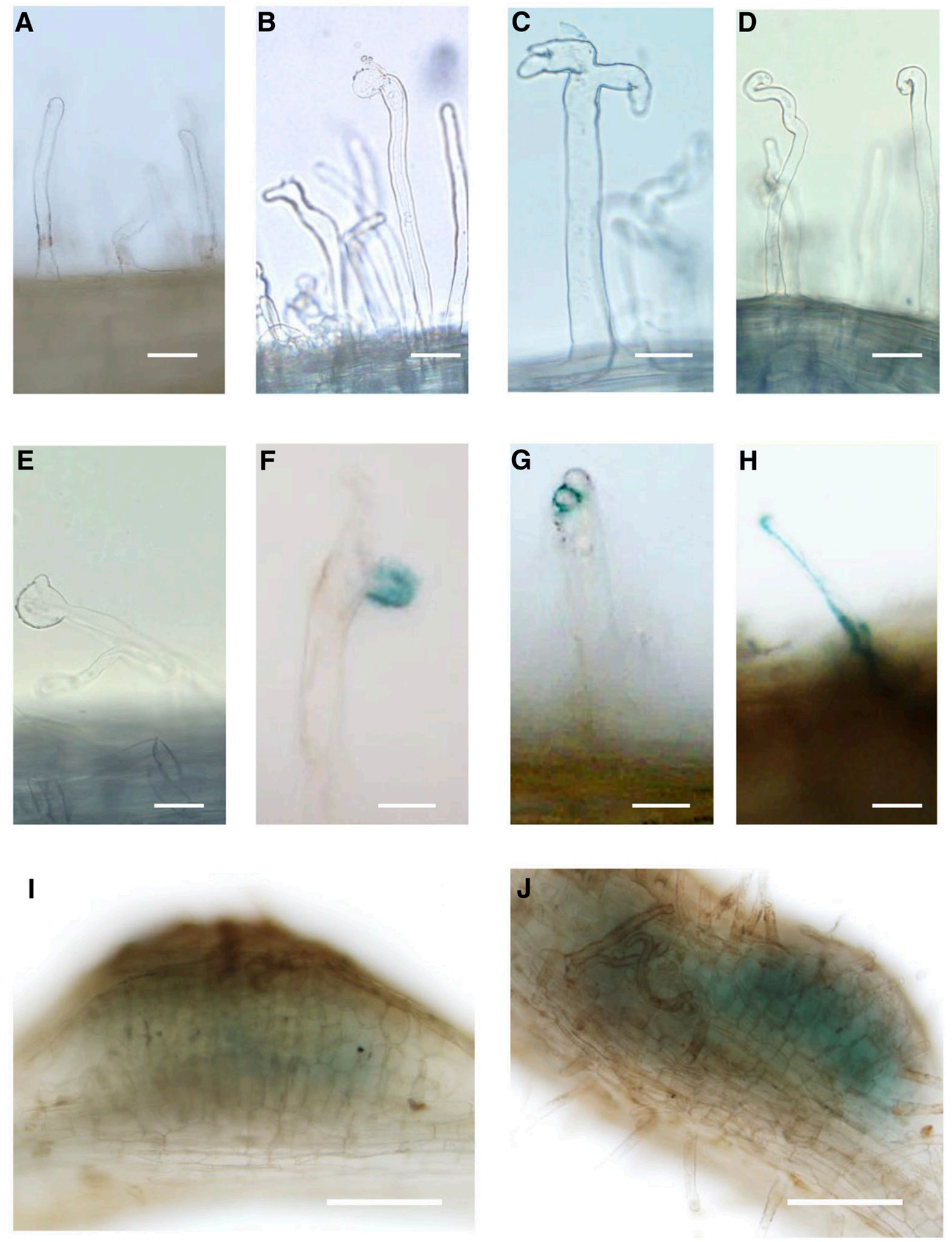

Fig. 4. Light micrograph of root hair, infection thread, and nodule primordium of Sophora flavescens inoculated by different rhizobia. A, Uninoculated root hairs at 6 days. B and C, Root hairs, 6 days after inoculation (dai) with Sinorhizobium fredii CCBAU 45436. D and E, Root hairs, 6 dai with Rhizobium yanglingense CCBAU 01603. F, Aggregating cells of the lacZ-labeled Sinorhizobium fredii CCBAU 45436 surrounding the tip of a biforked root hair, 10 dai. G, Infection pocket formed by the lacZ-labeled $R$. yanglingense CCBAU 01603, 10 dai. H, Infection thread induced by lacZ-labeled Sinorhizobium fredii CCBAU 45436, 11 dai. I and J, Nodule primordium induced by lacZ-labeled Sinorhizobium fredii CCBAU 45436 and $R$. yanglinense CCBAU 01603 , respectively, both at 15 dai. Bars: $40 \mu \mathrm{m}$ in $\mathrm{A}, \mathrm{B}, \mathrm{D}, \mathrm{E}$, and $\mathrm{H} ; 20 \mu \mathrm{m}$ in $\mathrm{C}, \mathrm{F}$, and $\mathrm{G}$; and $60 \mu \mathrm{m}$ in I and $\mathrm{J}$. 

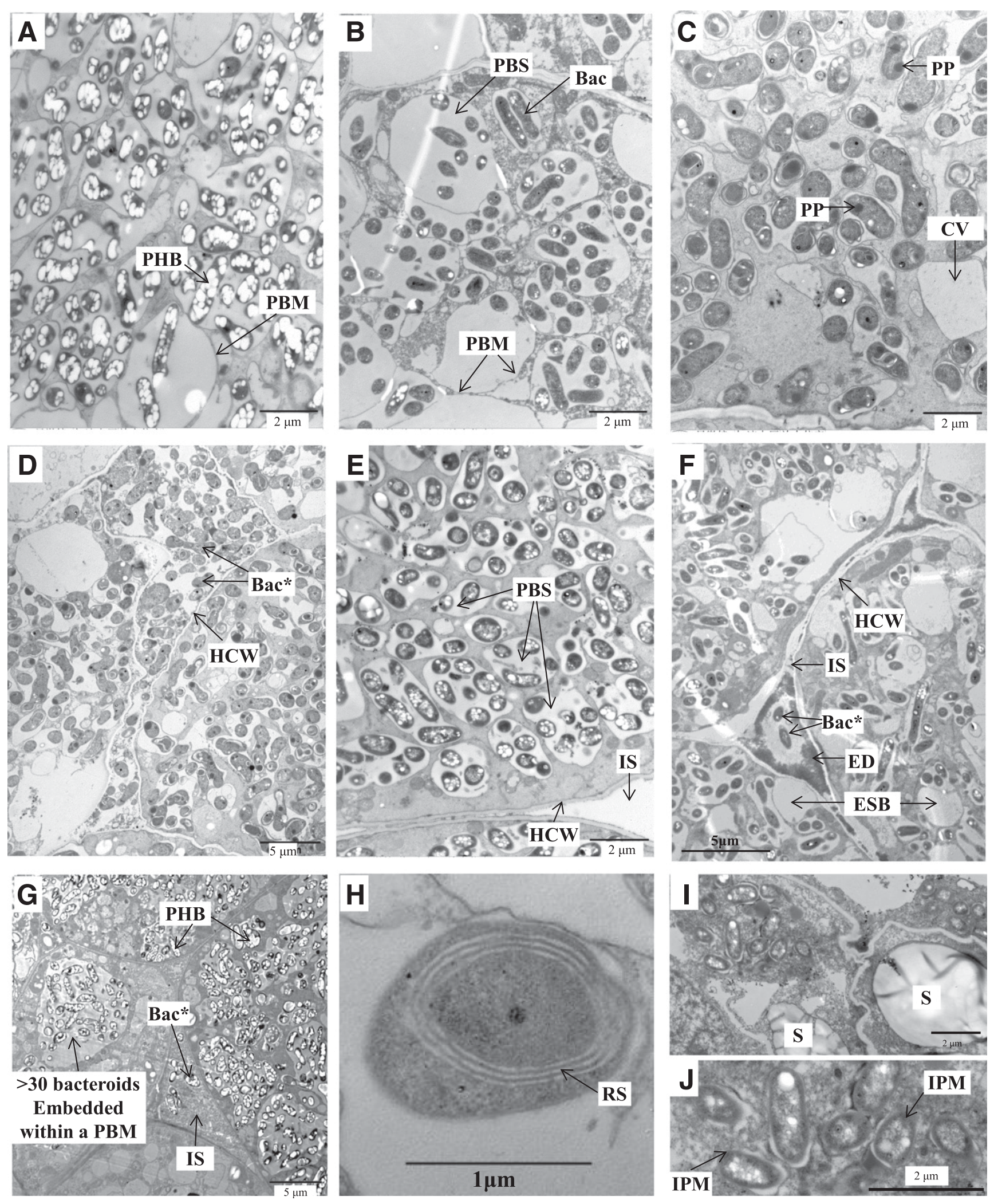

Fig. 5. Electron microscope of nodule section showing the characteristics of bacteroids of different rhizobia. All the sections were from zone III (i.e., the $\mathrm{N}_{2}$ fixation zone). A, Bradyrhizobium elkanii USDA $76^{\mathrm{T}}$; B, Mesorhizobium septentrionale CCBAU 03399; C, D, and H, Mesorhizobium loti NZP 2213 ${ }^{\mathrm{T}}$; E, Sinorhizobium sp. strain NGR 234; F, Bradyrhizobium arachidis CCBAU $051107^{\mathrm{T}}$; G, Sinorhizobium meliloti CCBAU 01199; I and J, Burkholderia tuberum LMG 21444 ${ }^{\mathrm{T}}$. Bac, bacteroid in symbiosome; Bac*, bacteroid in intercellular wall; HCW, host cell wall; IS, intercellular space; ED, electron-dense material; $\mathrm{CV}$, cytoplasmic vacuole; PP, electron-opaque polyphosphate inclusions; RS, ring and space surrounding an electron-opaque inclusion; PBS, peribacteroid space; ESB, empty symbiotic bubble; PBM, peribacteroid membrane; S, starch grains in plant cells; and IPM, incomplete peribacteroid membrane. 
CCBAU $051107^{\mathrm{T}}$ are bigger (Fig. 5). Regardless of the volume and size of PBS, all of these rhizobia fix nitrogen effectively on $S$. flavescens. The bigger PBS makes $S$. flavescens and some rhizobia good candidates for studying $\mathrm{pH}$ changes in the PBS and the transportation from PBS to plant cytoplasm across the PBM. The existence of bacteroids inside the intercellular spaces (Fig. 5D, F and G) without PBM suggests the movement of rhizobia through spaces between plant cells is ongoing.

Synthesis of starch grains and disrupted PBM were reported in ineffective nodules of Phaseolus vulgaris infected by a $\mathrm{C}_{4}$-dicarboxylic acid mutant of Rhizobium leguminosarum bv. phaseoli (Lafontaine et al. 1990). The incomplete PBM surrounding the bacteroid of Burkholderia tuberum and the accumulation of starch grains (Fig. 5I) further explain the ineffectiveness of nodules and the incompatibility between Burkholderia spp. and S. flavescens.

\section{PHB inclusion in the nodule of $S$. flavescens.}

The existence and accumulation of PHB in bacteroids is considered to stabilize cellular redox conditions (Anderson and Dawes 1990) and may provide energy and a carbon source to the bacteroids when they were released from nodules to soil (Ratcliff et al. 2008). PHB accumulation in bacteroids of S. flavescens nodules varied for different rhizobial strains. B. elkanii USDA $76^{\mathrm{T}}$, Sinorhizobium sp. strain NGR 234, and Sinorhizobium meliloti CCBAU 01199 synthesized a great amount of PHB within bacteroids, while M. loti NZP $2213^{\mathrm{T}}$ and $M$. amorphae CCBAU 03399 synthesized few PHB (Fig. 5). However, the $S$. flavescens inoculated with all these strains fix nitrogen efficiently, which is consistent with previous reports that strains unable to synthesize PHB or glycogen are still able to form nodules and fix nitrogen (Wang et al. 2007). So, the synthesis of PHB in bacteroids of $S$. flavescens is strain-dependent and may not be always stringently related to the efficiency of nitrogen fixation.

\section{Conclusion and remarks.}

Sophora flavescens is an extremely promiscuous legume for rhizobial symbionts in natural environments as well as under laboratory conditions. It has no strong preference for either the chromosomal or symbiotic gene backgrounds of rhizobia. Some narrow host-range rhizobia, e.g., different biovars of Rhizobium leguminosarum, Mesorhizobium huakuii, and M. loti could nodulate and fix nitrogen efficiently on S. flavescens. A clear biogeographic pattern exists for $S$. flavescens-nodulating rhizobia belonging to different species and distinct symbiotic gene types; however, this pattern is possibly affected by the soil conditions. Typical RHI is found in the rhizobial entry to $S$. flavescens. Most $\alpha$-rhizobia form functionally indeterminate nodules, while representative $\beta$-rhizobia induce inefficient nodules on $S$. flavescens. In addition, initial records indicate as many as 10 bacteroids could be included in a single symbiosome and that the PHB synthesis in bacteroids of S. flavescens is strain-dependent.

Based on the results obtained in the this study, it seems worthwhile to investigate i) whether the nod genes (or Nod factors) play the same role in invasion via RHI; ii) how the development of bacteroids of a rhizobial species (e.g., Bradyrhizobium arachidis) in the swollen (Arachis hypogaea) or nonswollen (S. flavescens) host plants differ; iii) whether the number of bacteroids in the symbiosome and the synthesis of PHB affect the nitrogen fixation of the nodules; and iv) how the legume selects distinct rhizobia in different environments.

\section{MATERIALS AND METHODS}

Nodule sampling and isolation of rhizobia.

Root nodules of cultured Sophora flavescens were collected from 18 sampling sites in the provinces of Shanxi, Shaanxi, and Liaoning, corresponding to three different ecoregions (I, II, and III) of China (Table 1; Fig. 2), in July through August of 2012 and 2013. At least five plants were surveyed and more than three nodules were collected per plant grown in cultivated $S$. flavescens fields without rhizobial inoculation history. Sampling, transportation, and isolation of root-nodule bacteria followed the methods of Zhang et al. (2011), except for the replacement of $0.2 \%$ mercury bichloride $\left(\mathrm{HgCl}_{2}\right)$ with $2.5 \%$ sodium hypochlorite $(\mathrm{NaClO})$ and the altering of sterilization time to $8 \mathrm{~min}$ for the surface-sterilization of nodules. Culture on plates or in broth of yeast-mannitol (YM) medium (Vincent 1970) and the storage methods were the same as described by Zhang et al. (2011).

\section{Soil sampling and characterization.}

Soil was sampled and treated for determining chemical properties following the methods of Zhang et al. (2011) and Yan et al. (2014). Contents of available N, P, K, and pH of soil factors were analyzed in the Plant Nutrient and Resource Research Institution, Beijing Academy of Agriculture and Forestry Sciences (Beijing), using the standard methods (Yan et al. 2014).

\section{Estimating genetic diversity of rhizobia}

by MLSA of housekeeping and symbiotic genes.

Total DNA was extracted from the bacterial culture in TY broth (tryptone, $5 \mathrm{~g}$; yeast extract, $3 \mathrm{~g}$; $\mathrm{CaCl}_{2}, 0.6 \mathrm{~g}$; distilled water, 1 liter; $\mathrm{pH}$ 7.0) using the GuTC (guanidiniumTris-CDTA buffer with celite) method (Terefework et al. 2001). The recA gene was amplified in all rhizobial isolates, using primers recA41F and recA640R and the polymerase chain reaction (PCR) procedure described by Vinuesa et al. (2005). The PCR products were sequenced directly using the recA41F primer. All of the recA sequences acquired in this study were used to determine their identities with Clustal W software (Larkin et al. 2007). Isolates sharing identical sequences were designated as a single genotype. Based on the grouping results from $r e c A$ gene analysis, representative isolates of different genotypes were chosen to amplify the other two housekeeping genes, glnII and $a t p D$, using primer pairs glnII12F and glnII689R and atpD255F and atpD782R, respectively, with protocols described by Vinuesa et al. (2005). Two symbiotic genes, nifH and nodC, were amplified separately using the primer pairs nifHF and nifHR (Laguerre et al. 2001) and nodCF540 and nodCR1160 (Sarita et al. 2005), following the corresponding protocols. All the PCR products were sequenced using the corresponding forward primers. The acquired sequences and the related sequences obtained from the GenBank database by BLASTn searching were aligned and a maximumlikelihood phylogenetic tree was constructed, using the software MEGA 6.0 (Tamura et al. 2013). The phylogenetic trees were bootstrapped with 1,000 replications.

To estimate the community structure and species richness of S. flavescens rhizobia, genospecies were defined based upon the result of MLSA with the concatenated $\operatorname{recA}$, atpD, and glnII sequences, using the average nucleotide identity of $96 \%$ as threshold of genospecies ( $\mathrm{Ji}$ et al. 2015). Rhizobial diversity, species richness, and evenness in different sampling sites (S1 to S18) were estimated by three popular alpha ecological indexes (Hill et al. 2003), i.e., the Shannon-Wiener $\left(H^{\prime}\right)$ and Simpson $(D)$ indexes to represent diversity considering both the genospecies richness and evenness, respectively, in a community (here the sampling sites) and the Pielou index $(J)$ to represent genospecies evenness in the community. These indexes of biodiversity, implemented in the CRAN vegan package (version 1.17-4), were calculated by the $\mathrm{R}$ statistical language (R Core Team 2014). 
Correspondence analysis among the rhizobial genomic species, ecoregions, and soil characters.

Redundancy analysis (RDA) (Rao 1964), the canonical version of principal component analysis, was used to look for possible relationships between the soil factors and different rhizobial distributions in the 18 sampling sites (Table 1). Community data for rhizobial genospecies (Table 2) were preanalyzed by detrended correspondence analysis (DCA), using CANOCO software 4.5 (Microcomputer Power, Ithaca, NY, U.S.A.) (Lepš and Šmilauer 2003). In the DCA, the models of species response to environmental variables and the length of the gradient (first axis) were 4.709 , so both the linear model and the unimodal model are suitable. After further model tests, RDA proved to be the best method.

GenGIS software was used to merge geographic, ecological, and phylogenetic biodiversity data in a single interactive visualization and analysis environment (Parks et al. 2009). Four files, including the China map (in shapefile format), the geographic location of the sampling sites (in comma-separated values [.csv] format), the statistic ratio (Table 2) of genospecies in each site (in .csv format) and the hierarchical cluster dendrogram of the ratio of genospecies in each site (in Newick format) were prepared and were introduced in sequence to GenGIS software, following the GenGIS manual.

\section{Nodulation tests.}

The nodulation capability of all the isolates was tested on the host plant $S$. flavescens. To study the symbiotic promiscuity of $S$. flavescens, representative strains belonging to different rhizobial species in classes $\alpha$ - and $\beta$-Proteobacteria with different nodC types and whose leguminous hosts in different crossnodulation groups were tested for nodulation capability and symbiotic effectiveness on $S$. flavescens (Table 3). These strains were obtained from CCBAU or from other culture collections (Table 3). Some representative strains isolated from $S$. flavescens were also used to inoculate other related legumes (Table 3). Seeds of $S$. flavescens were immersed in concentrated sulphuric acid $\left(\mathrm{H}_{2} \mathrm{SO}_{4}\right)$ for 20 to $30 \mathrm{~min}$. After discarding the $\mathrm{H}_{2} \mathrm{SO}_{4}, 95 \%$ ethanol was added to rinse the seeds. Then, seeds were surfacesterilized using $2.5 \%$ sodium hypochlorite $(\mathrm{NaClO})$ for $15 \mathrm{~min}$. After being rinsed in sterilized distilled water seven times, the seeds were transferred onto a water-agar $(0.8 \%, \mathrm{wt} / \mathrm{vol})$ plate for germination for 3 days. The germinated seedlings were transplanted into the upper layer of a Leonard jar containing sterilized vermiculite moistened with nitrogen-free nutrient solution (Vincent 1970). A 1-ml bacterial suspension cultured to logarithmic phase was added to the rhizosphere of the seedlings. The noninoculated plants were used as negative control. Plants were moved to the greenhouse with the rotation of light for $16 \mathrm{~h}$ at $25^{\circ} \mathrm{C}$ and dark for $8 \mathrm{~h}$ at $23^{\circ} \mathrm{C}$. Nodulation was checked 45 days after inoculation. The color of the mature root-nodule section (red or white) and the leaves of the plant (bright green or yellow green) were observed, to evaluate plant growth and nitrogen-fixing efficiency. Chlorophyll content of the leaves was measured, using a chlorophyll meter (Spad 502 Plus, Konica Minolta, Inc., Osaka, Japan) to estimate the symbiotic effectiveness of the nodules indirectly.

\section{Microscopy observation.}

For observing the nodule structure under bright-field microscopy, samples were prepared as follows. Three nodules were excised from $S$. flavescens plants and were fixed with freshly prepared $4 \%$ paraformaldehyde and $0.25 \%$ glutaraldehyde in $10 \mathrm{mM}$ sodium phosphate buffer ( $\mathrm{pH}$ 6.8) supplemented with $100 \mathrm{mM} \mathrm{NaCl}$. Nodules in $1 \%$ toluidine blue liquor were placed in vacuum conditions for 20 to $30 \mathrm{~min}$ to improve infiltration and staining. Specimens were washed in the same buffer and were dehydrated in a graded ethanol series $(75,90$, and $100 \%$, vol/vol). Then, they were infiltrated and embedded in JB-L5-tissue (Junjie Ecoectronics, Wuhan, China). Semithin slides (4 to $5 \mu \mathrm{m}$ thickness) were cut, using a LEICA Microm RM2016 microtome (Wetzlar, Germany), and were photographed using Olympus U-HSCBM bright-field microscopy.

Observation of bacteroids inside the nodules was performed using a JEM-1230 transmission electron microscope (TEM). Root nodules were fixed in $2.5 \%$ glutaraldehyde for more than $2 \mathrm{~h}$, were washed with $0.1 \mathrm{M}$ phosphate buffer three times, were fixed in $1 \%$ osmium for $2 \mathrm{~h}$, and were dehydrated in a graded acetone $(30,50,70,80,90$, and $100 \%$, vol/vol, for 5 to $15 \mathrm{~min}$ each). Then, nodules were embedded in SPURR epoxy resin, were polymerized, and were sliced longitudinally into ultraslices, using a LEICA UC6 ultra microtome. After being stained with both uranyl acetate and lead citrate, the ultraslice was observed with TEM.

\section{Observation of the infection process.}

To observe the infection process, two representative strains, $R$. yanglingense CCBAU 01603 and Sinorhizobium fredii CCBAU 45436 (both are resistant to nalidixic acid [NA], $30 \mu \mathrm{g} \mathrm{ml}^{-1}$ ), were labeled with the lac $Z$ reporter gene by triparental mating as previously described (Hoekema et al. 1983; Vadawale et al. 2011). Briefly, Escherichia coli DH5 $\alpha$ with the lacZ reporter plasmid PGD926 (tetracycline resistant, $20 \mu \mathrm{g} \mathrm{ml}^{-1}$ ) (Ditta et al. 1985) as the donor strain, E. coli DH5 $\alpha$ with pRK2013 (kanamycin resistant, $50 \mu \mathrm{g} \mathrm{ml}^{-1}$ ) (Ditta et al. 1980) as the helper strain, and the rhizobial strain CCBAU 01603 (or CCBAU 45436) as the recipient strain were incubated in LuriaBertani (for $E$. coli at $37^{\circ} \mathrm{C}$ ) or TY (for rhizobia at $28^{\circ} \mathrm{C}$ ) broth to the potential phase. Cultures were collected by centrifugation, were resuspended in $1 \mathrm{ml}$ of TY broth, and were mixed in a ratio of 3:2:10 (vol:vol:vol) on TY agar for mating for $24 \mathrm{~h}$ at $28^{\circ} \mathrm{C}$. The mating culture was spread onto the YM agar containing two antibiotics, tetracycline and NA, for selecting the conjugants.

After germination on water-agar plates for 3 days, seedlings of $S$. flavescens were transferred to vermiculite-containing Leonard jars as described above. Three days later, the seedlings were inoculated with $1 \mathrm{ml}$ of lacZ-labeled logarithmic growing conjugants in YM broth containing corresponding antibiotics. At an interval of 3 days, plants were taken out to observe the rhizobial infection and nodule development. Plant roots inoculated with the lacZ-labeled strain CCBAU 01603 (or CCBAU 45436) were fixed and were stained using standard procedures (Marchetti et al. 2010). Samples were observed using a bright-field microscope (Olympus BX53 microscope with DP72 capture).

\section{ACKNOWLEDGMENTS}

Many thanks to X. Liu, W. Liu, M. Andrews, F. John, M. Sadowsky, C. Vereecke, Y. G. Li, and L. Wang for providing us with reference strains or plasmids. Thanks to $\mathrm{Z}$. Guan and $\mathrm{S}$. Wu for their help on collecting nodules in the fields. Appreciations go to M. Y. Li, A. Zimmerman and T. Godfrey for their improvement for the English of the manuscript. Thanks to D. X. Yang for his help on polishing the photos. This research was supported by China Natural Foundation (No. 31270052), Chinese Universities Scientific Fund (2015TC001) and Northern China Standardized Plant Base Optimization and Upgrading and Series Products Comprehensive Development of Sophora flavescens (No. 2011BA107B03).

\section{LITERATURE CITED}

Anderson, A. J., and Dawes, E. A. 1990. Occurrence, metabolism, metabolic role, and industrial uses of bacterial polyhydroxyalkanoates. Microbiol. Rev. 54:450-472.

Angus, A. A., Lee, A., Lum, M. R., Shehayeb, M., Hessabi, R., Fujishige, N. A., Yerrapragada, S., Kano, S., Song, N., Yang, P., de los Santos, P. E., de Faria, S. M., Dakora, F. D., Weinstock, G., and Hirsch, A. M. 2013. 
Nodulation and effective nitrogen fixation of Macroptilium atropurpureum (siratro) by Burkholderia tuberum, a nodulating and plant growth promoting beta-proteobacterium, are influenced by environmental factors. Plant Soil 369:543-562.

Ba, S., Willems, A., de Lajudie, P., Roche, P., Jeder, H., Quatrini, P., Neyra, M., Ferro, M., Promé, J.-C., Gillis, M., Boivin-Masson, C., and Lorquin, J. 2002. Symbiotic and taxonomic diversity of rhizobia isolated from Acacia tortilis subsp. raddiana in Africa. Syst. Appl. Microbiol. 25:130-145.

Bal, A. K., Sen, D., and Weaver, R. W. 1985. Cell wall (outer membrane) of bacteroids in nitrogen-fixing peanut nodules. Curr. Microbiol. 12:353-356.

Barker, D. G., Bianchi, S., Blondon, F., Dattée, Y., Duc, G., Essad, S., Flament, P., Gallusci, P., Génier, G., and Guy, P. 1990. Medicago truncatula, a model plant for studying the molecular genetics of the Rhizobium-legume symbiosis. Plant Mol. Biol. Rep. 8:40-49.

Crow, C. L., Jarvis, B. D. W., and Greenwood, R. M. 1981. Deoxyribonucleic acid homologies among acid-producing strains of Rhizobium. Int. J. Syst. Bacteriol. 31:152-172.

Dall'Agnol, R. F., Ribeiro, R. A., Delamuta, J. R., Ormeño-Orrillo, E., Rogel, M. A., Andrade, D. S., Martínez-Romero, E., and Hungria, M. 2014. Rhizobium paranaense sp. nov., an effective $\mathrm{N}_{2}$-fixing symbiont of common bean (Phaseolus vulgaris L.) with broad geographical distribution in Brazil. Int. J. Syst. Evol. Microbiol. 64:3222-3229.

Dénarié, J., Debellé, F., and Promé, J. C. 1996. Rhizobium lipochitooligosaccharide nodulation factors: Signaling molecules mediating recognition and morphogenesis. Annu. Rev. Biochem. 65:503-535.

Ditta, G., Schmidhauser, T., Yakobson, E., Lu, P., Liang, X. W., Finlay, D. R., Guiney, D., and Helinski, D. R. 1985. Plasmids related to the broad host range vector, pRK290, useful for gene cloning and for monitoring gene expression. Plasmid 13:149-153.

Ditta, G., Stanfield, S., Corbin, D., and Helinski, D. R. 1980. Broad host range DNA cloning system for gram-negative bacteria: Construction of a gene bank of Rhizobium meliloti. Proc. Natl. Acad. Sci. U.S.A. 77: 7347-7351.

Ferguson, B. J. 2013. Rhizobia and legume nodulation genes. Academic Press Elsevier, New York.

Fernández-Lopez, M., Goormachtig, S., Gao, M., D’Haeze, W., Van Montagu, M., and Holsters, M. 1998. Ethylene-mediated phenotypic plasticity in root nodule development on Sesbania rostrata. Proc. Natl. Acad. Sci. U.S.A. 95:12724-12728.

Garau, G., Yates, R. J., Deiana, P., and Howieson, J. G. 2009. Novel strains of nodulating Burkholderia have a role in nitrogen fixation with papilionoid herbaceous legumes adapted to acid, infertile soils. Soil Biol. Biochem. 41:125-134.

Han, L. L., Wang, E. T., Han, T. X., Liu, J., Sui, X. H., Chen, W. F., and Chen, W. X. 2009. Unique community structure and biogeography of soybean rhizobia in the saline-alkaline soils of Xinjiang, China. Plant Soil 324:291-305.

Han, R., Takahashi, H., Nakamura, M., Bunsupa, S., Yoshimoto, N., Yamamoto, H., Suzuki, H., Shibata, D., Yamazaki, M., and Saito, K. 2015. Transcriptome analysis of nine tissues to discover genes involved in the biosynthesis of active ingredients in Sophora flavescens. Biol. Pharm. Bull. 38:876-883

Han, T. X., Wang, E. T., Han, L. L., Chen, W. F., Sui, X. H., and Chen, W. X. 2008. Molecular diversity and phylogeny of rhizobia associated with wild legumes native to Xinjiang, China. Syst. Appl. Microbiol. 31: 287-301.

Hill, T. C. J., Walsh, K. A., Harris, J. A., and Moffett, B. F. 2003. Using ecological diversity measures with bacterial communities. FEMS (Fed. Eur. Microbiol. Soc.) Microbiol. Ecol. 43:1-11.

Hoekema, A., Hirsch, P., and Hooykass, P. 1983. A binary plant vector strategy based on separation of the vir and TDNA regions of the Agrobacterium tumefaciens Ti plasmid. Nature 303:179-180.

Ji, Z. J., Yan, H., Cui, Q. G., Wang, E. T., Chen, W. X., and Chen, W. F. 2015. Genetic divergence and gene flow among Mesorhizobium strains nodulating the shrub legume Caragana. Syst. Appl. Microbiol. 38: 176-183.

Jiao, Y. S., Yan, H., Ji, Z. J., Liu, Y. H., Sui, X. H., Wang, E. T., Guo, B. L., Chen, W. X., and Chen, W. F. 2015a. Rhizobium sophorae sp. nov. and Rhizobium sophoriradicis sp. nov., nitrogen-fixing rhizobial symbionts of the medicinal legume Sophora flavescens. Int. J. Syst. Evol. Microbiol. 65:497-503.

Jiao, Y. S., Yan, H., Ji, Z. J., Liu, Y. H., Sui, X. H., Zhang, X. X., Wang, E. T., Chen, W. X., and Chen, W. F. 2015b. Phyllobacterium sophorae sp. nov., a symbiotic bacterium isolated from root nodules of Sophora flavescens. Int. J. Syst. Evol. Microbiol. 65:399-406.

Lafontaine, P. J., Benhamou, N., and Antoun, H. 1990. The occurrence of unusual laminated structures rich in $\beta$-1,4-glucans in plastids of Phaseolus vulgaris root-nodule cells infected by an ineffective
C4-dicarboxylic-acid mutant of Rhizobium leguminosarum bv. phaseoli. Planta 180:312-323.

Laguerre, G., Louvrier, P., Allard, M. R., and Amarger, N. 2003. Compatibility of rhizobial genotypes within natural populations of Rhizobium leguminosarum biovar viciae for nodulation of host legumes Appl. Environ. Microbiol. 69:2276-2283.

Laguerre, G., Nour, S. M., Macheret, V., Sanjuan, J., Drouin, P., and Amarger, N. 2001. Classification of rhizobia based on nodC and nifH gene analysis reveals a close phylogenetic relationship among Phaseolus vulgaris symbionts. Microbiology 147:981-993.

Larkin, M. A., Blackshields, G., Brown, N. P., Chenna, R., McGettigan, P. A., McWilliam, H., Valentin, F., Wallace, I. M., Wilm, A., Lopez, R., Thompson, J. D., Gibson, T. J., and Higgins, D. G. 2007. Clustal W and Clustal X version 2.0. Bioinformatics 23:2947-2948.

Lei, L., Chen, L., Shi, X. F., Li, Y. X., Wang, J. Y., Chen, D. S., Xie, F. L., and Li, Y. G. 2014. A nodule-specific lipid transfer protein AsE246 participates in transport of plant-synthesized lipids to symbiosome membrane and is essential for nodule organogenesis in Chinese milk vetch. Plant Physiol. 164:1045-1058.

Lepš, J., and Šmilauer, P. 2003. Multivariate analysis of ecological data using CANOCO. Cambridge University Press, Cambridge, United Kingdom.

Li, Q. Q., Wang, E. T., Chang, Y. L., Zhang, Y. Z., Zhang, Y. M., Sui, X. H., Chen, W. F., and Chen, W. X. 2011. Ensifer sojae sp. nov., isolated from root nodules of Glycine max grown in saline-alkaline soils. Int. J. Syst. Evol. Microbiol. 61:1981-1988.

Liu, W. Y., Ridgway, H. J., James, T. K., James, E. K., Chen, W. M., Sprent, J. I., Young, J. P., and Andrews, M. 2014. Burkholderia sp. induces functional nodules on the South African invasive legume Dipogon lignosus (Phaseoleae) in New Zealand soils. Microb. Ecol. 68:542-555.

Lu, Y. L., Chen, W. F., Wang, E. T., Guan, S. H., Yan, X. R., and Chen, W. X. 2009. Genetic diversity and biogeography of rhizobia associated with Caragana species in three ecological regions of China. Syst. Appl. Microbiol. 32:351-361.

Madsen, L. H., Tirichine, L., Jurkiewicz, A., Sullivan, J. T., Heckmann, A. B., Bek, A. S., Ronson, C. W., James, E. K., and Stougaard, J. 2010 The molecular network governing nodule organogenesis and infection in the model legume Lotus japonicus. Nat. Commun. 1:10.

Marchetti, M., Capela, D., Glew, M., Cruveiller, S., Chane-Woon-Ming, B., Gris, C., Timmers, T., Poinsot, V., Gilbert, L. B., Heeb, P., Médigue, C., Batut, J., and Masson-Boivin, C. 2010. Experimental evolution of a plant pathogen into a legume symbiont. PLoS Biol. 8:e1000280.

Margaret, I., Lucas, M. M., Acosta-Jurado, S., Buendía-Clavería, A. M. Fedorova, E., Hidalgo, Á., Rodríguez-Carvajal, M. A., RodriguezNavarro, D. N., Ruiz-Sainz, J. E., and Vinardell, J. M. 2013. The Sinorhizobium fredii $\mathrm{HH} 103$ lipopolysaccharide is not only relevant at early soybean nodulation stages but also for symbiosome stability in mature nodules. PLoS One 8:e74717.

Michiels, J., Dombrecht, B., Vermeiren, N., Xi, C., Luyten, E., and Vanderleyden, J. 1998. Phaseolus vulgaris is a non-selective host for nodulation. FEMS (Fed. Eur. Microbiol. Soc.) Microbiol. Ecol. 26: 193-205.

Moulin, L., Munive, A., Dreyfus, B., and Boivin-Masson, C. 2001. Nodulation of legumes by members of the $\beta$-subclass of Proteobacteria. Nature 411:948-950.

Okubo, T., Fukushima, S., and Minamisawa, K. 2012. Evolution of Bradyrhizobium-Aeschynomene mutualism: Living testimony of the ancient world or highly evolved state? Plant Cell Physiol. 53:2000-2007.

Oono, R., and Denison, R. F. 2010. Comparing symbiotic efficiency between swollen versus nonswollen rhizobial bacteroids. Plant Physiol. 154:1541-1548

Op den Camp, R. H., Polone, E., Fedorova, E., Roelofsen, W., Squartini, A., Op den Camp, H. J., Bisseling, T., and Geurts, R. 2012. Nonlegume Parasponia andersonii deploys a broad rhizobium host range strategy resulting in largely variable symbiotic effectiveness. Mol. Plant-Microbe Interact. 25:954-963

Parks, D. H., Porter, M., Churcher, S., Wang, S., Blouin, C., Whalley, J., Brooks, S., and Beiko, R. G. 2009. GenGIS: A geospatial information system for genomic data. Genome Res. 19:1896-1904.

Pueppke, S. G., and Broughton, W. J. 1999. Rhizobium sp. strain NGR234 and $R$. fredii USDA257 share exceptionally broad, nested host ranges. Mol. Plant-Microbe Interact. 12:293-318.

R Core Team. (2014). R: A language and environment for statistical computing. R Foundation for Statistical Computing, Vienna, Austria. URL: http://www.R-project.org/.

Rao, C.R. 1964. The use and interpretation of principal component analysis in applied research. Sankhya: Ind J Stat (1961-2002) 26:329-358. 
Ratcliff, W. C., Kadam, S. V., and Denison, R. F. 2008. Poly-3hydroxybutyrate (PHB) supports survival and reproduction in starving rhizobia. FEMS (Fed. Eur. Microbiol. Soc.) Microbiol. Ecol. 65: 391-399.

Sajnaga, E., Malek, W., Lotocka, B., Stepkowski, T., and Legocki, A. 2001. The root-nodule symbiosis between Sarothamnus scoparius L. and its microsymbionts. Antonie van Leeuwenhoek 79:385-391.

Sarita, S., Sharma, P. K., Priefer, U. B., and Prell, J. 2005. Direct amplification of rhizobial nodC sequences from soil total DNA and comparison to nodC diversity of root nodule isolates. FEMS (Fed. Eur. Microbiol. Soc.) Microbiol. Ecol. 54:1-11.

Sprent, J. I. 2001. Nodulation in Legumes. Royal Botanic Gardens, Kew, U.K.

Sprent, J. I. 2009. Legume Nodulation: A Global Perspective. WileyBlackwell, Chichester, U.K.

Tamura, K., Stecher, G., Peterson, D., Filipski, A., and Kumar, S. 2013. MEGA6: Molecular evolutionary genetics analysis version 6.0. Mol. Biol. Evol. 30:2725-2729.

Tan, H. W., Heenan, P. B., De Meyer, S. E., Willems, A., and Andrews, M. 2015. Diverse novel mesorhizobia nodulate New Zealand native Sophora species. Syst. Appl. Microbiol. 38:91-98.

Terefework, Z., Kaijalainen, S., and Lindström, K. 2001. AFLP fingerprinting as a tool to study the genetic diversity of Rhizobium galegae isolated from Galega orientalis and Galega officinalis. J. Biotechnol. 91:169-180.

Vadawale, A., Mihani, R., Mathew, A., and Robin, P. 2011. Transformation of Agrobacterium tumifascience LBA 4404 with a cholin oxidase-cox gene conferring salinity tolerance. $2^{\text {nd }}$ Int. Confer Agricul Anim Sci 22:175-181.

Verástegui-Valdés, M. M., Zhang, Y. J., Rivera-Orduña, F. N., Cheng, H. P., Sui, X. H., and Wang, E. T. 2014. Microsymbionts of Phaseolus vulgaris in acid and alkaline soils of Mexico. Syst. Appl. Microbiol. 37:605-612.

Vincent, J. M. 1970. A manual for the Practical Study of Root Nodule Bacteria. International Biological Programme. Blackwell Scientific, Oxford

Vinuesa, P., Silva, C., Werner, D., and Martínez-Romero, E. 2005. Population genetics and phylogenetic inference in bacterial molecular systematics: The roles of migration and recombination in Bradyrhizobium species cohesion and delineation. Mol. Phylogenet. Evol. 34:29-54.

Wang, C. X., Saldana, M., Sheng, X. Y., Shelswell, K. J., Walsh, K. T., Sobral, B. W., and Charles, T. C. 2007. Roles of poly-3-hydroxybutyrate (PHB) and glycogen in symbiosis of Sinorhizobium meliloti with Medicago sp. Microbiology 153:388-398.
Wang, R., Chang, Y. L., Zheng, W. T., Zhang, D., Zhang, X. X., Sui, X. H., Wang, E. T., Hu, J. Q., Zhang, L. Y., and Chen, W. X. 2013. Bradyrhizobium arachidis sp. nov., isolated from effective nodules of Arachis hypogaea grown in China. Syst. Appl. Microbiol. 36: 101-105.

Wang, S. M., Hao, B. H., Li, J. R., Gu, H. L., Peng, J. L., Xie, F. L., Zhao, X. Y., Frech, C., Chen, N. S., Ma, B. G., and Li, Y. G. 2014. Wholegenome sequencing of Mesorhizobium huakuii 7653R provides molecular insights into host specificity and symbiosis island dynamics. BMC Genomics 15:440.

Weir, B. S., Turner, S. J., Silvester, W. B., Park, D.-C., and Young, J. M. 2004. Unexpectedly diverse Mesorhizobium strains and Rhizobium leguminosarum nodulate native legume genera of New Zealand, while introduced legume weeds are nodulated by Bradyrhizobium species. Appl. Environ. Microbiol. 70:5980-5987.

Yan, J., Han, X. Z., Ji, Z. J., Li, Y., Wang, E. T., Xie, Z. H., and Chen, W. F. 2014. Abundance and diversity of soybean-nodulating rhizobia in black soil are impacted by land use and crop management. Appl. Environ. Microbiol. 80:5394-5402.

Yang, S. M., Tang, F., Gao, M. Q., Krishnan, H. B., and Zhu, H. Y. 2010 $R$ gene-controlled host specificity in the legume-rhizobia symbiosis. Proc. Natl. Acad. Sci. U.S.A. 107:18735-18740.

Zhang, J. J., Liu, T. Y., Chen, W. F., Wang, E. T., Sui, X. H., Zhang, X. X., Li, Y., Li, Y., and Chen, W. X. 2012. Mesorhizobium muleiense sp. nov., nodulating with Cicer arietinum L. Int. J. Syst. Evol. Microbiol. 62: 2737-2742

Zhang, Y. M., Li, Y., Jr., Chen, W. F., Wang, E. T., Tian, C. F., Li, Q. Q., Zhang, Y. Z., Sui, X. H., and Chen, W. X. 2011. Biodiversity and biogeography of rhizobia associated with soybean plants grown in the North China Plain. Appl. Environ. Microbiol. 77:6331-6342.

Zhao, L. F., Deng, Z. S., Yang, W. Q., Cao, Y., Wang, E. T., and Wei, G. H 2010. Diverse rhizobia associated with Sophora alopecuroides grown in different regions of Loess Plateau in China. Syst. Appl. Microbiol. 33: 468-477.

Zheng, W. T., Li, Y., Jr., Wang, R., Sui, X. H., Zhang, X. X., Zhang, J. J., Wang, E. T., and Chen, W. X. 2013. Mesorhizobium qingshengii sp. nov., isolated from effective nodules of Astragalus sinicus. Int. J. Syst. Evol. Microbiol. 63:2002-2007.

\section{AUTHOR-RECOMMENDED INTERNET RESOURCE}

GenGIS website: http://kiwi.cs.dal.ca/GenGIS/Main_Page 